\title{
Hot Compressed Water Extraction of Lignin by Using a Flow-Through Reactor
}

\author{
Siti Machmudah ${ }^{1}$, Wahyudiono ${ }^{2}$, Hideki Kanda $^{2}$, Mitsuru Sasaki $^{3}$, and Motonobu Goto ${ }^{2, *}$ \\ 1 Department of Chemical Engineering, Sepuluh Nopember Institute of Technology, Kampus ITS, \\ Surabaya 60111, Indonesia \\ 2 Department of Chemical Engineering, Nagoya University, Furo-cho, Chikusa-ku, Nagoya 464-8603, Japan \\ 3 Graduate School of Science and Technology, Kumamoto University, 2-39-1 Kurokami, Kumamoto 860- \\ 8555, Japan \\ *E-mail: mgoto@nuce.nagoya-u.ac.jp
}

\begin{abstract}
Japanese rice straw, an agricultural by-product, was utilized for the extraction of lignin by hot compressed water at temperatures of $443-503 \mathrm{~K}$ and a pressure of $4.0 \mathrm{MPa}$ using a flow-through system, a simple and environmentally friendly extraction method requiring no chemicals other than water. Under these conditions, thermal softening of the Japanese rice straw occurred, allowing the removal of lignin via depolymerization reactions. Lignin as an extraction product was analyzed using utraviolet-visible (UV-vis) spectrophotometry. Lignin recovery approached $85 \%$ when the extraction was performed at 443 and $473 \mathrm{~K}$ with a flow rate of $4.67 \mathrm{ml} \mathrm{min}^{-1}$. At a constant residence time, recovery amounts increased with increasing flow rate at each temperature. The results suggested that this process may result in an advanced plant biomass components extraction technology.
\end{abstract}

Keywords: Biomass, extraction, lignin, rice straw, subcritical.

ENGINEERING JOURNAL Volume 19 Issue 4

Received 20 August 2014

Accepted 11 January 2015

Published 31 July 2015

Online at http://www.engj.org/

DOI:10.4186/ej.2015.19.4.25 


\section{Introduction}

Biomass is matter derived directly or indirectly from plants which is utilized in substantial amounts as energy or material. The main constituents of wood biomass are cellulose $(40 \sim 45 \mathrm{wt} \%)$, hemicellulose (25 35 wt \%), lignin (15 30 wt\%) and other compounds (up to $10 \mathrm{wt} \%$ ) [1]. Cellulose and hemicellulose can be enzymatically hydrolyzed to monomeric sugars after pre-treatment aiming at hydrolytic cleavage of its partially crystalline structure [2]. Recently, supercritical water treatment has been found possible without the addition of chemicals or oxygen, making it a potential method for pre-treatment of large quantities of biomass. This treatment causes specific hydrolysis of cellulose and hemicellulose and physically destructs tissues [2-5]. Lignin is another primary component of plant biomass and contains many oxygen functional groups. Phenolic chemicals can also be obtained from lignin by chemical degradation processes [5-10]. Lignin or biomass can be converted to gases by a gasification process; the major products from lignin gasification include $\mathrm{H}_{2}, \mathrm{CO}, \mathrm{CO}_{2}$ and $\mathrm{CH}_{4}$ [11-15].

The plant biomass thermal decomposition process requires that biomass be separated into its components, conventionally under subcritical conditions. This process is crucial for the complete and most efficient conversion of the lignin, hemicellulose, and cellulose to their highest-value products. For example, the extraction of lignin from wood is needed in pulp and paper production as well as for ethanol production. Hydrolysis occurs by the addition of acids, bases or organic solvents, a process necessitation neutralization in order to reduce corrosion of the reactor [16-18]; recycling of these chemicals is also necessary so as to reduce negative impacts on the environment as well as on subsequent process. To eliminate such costs, non-catalytic hydrothermal processes have been studied [19-22]. At elevated temperatures and pressures, liquid water can be used to fractionate biomass into its constituents [23, 24]. The ionic product of water changes in tandem with temperature [25]. Therefore, hot compressed water extraction is considered suitable for the hydrolysis process because it gives the highest ionic product. Mok and Antal 1992 [26] succeeded in solubilizing most hemicellulose together with lignin in hot compressed water using a tubular percolating reactor; this was performed for the production of xylitol and furfural from hemicellulose or as a pretreatment for enzymatic hydrolysis of cellulose. Rogalinski et al. 2008 [27] conducted liquid hot water pretreatment of rye straw and rye silage in both a batch and a continuous flow reactor; they reported that liquid hot water provides an excellent reaction medium for the pretreatment of biomass. High degrees of biomass solubilization are possible. Chandra et al. 2012 [28] conducted methane fermentation study on pretreated substrates of rice straw biomass revealed that $\mathrm{NaOH}$ and hydrothermal pretreatments results into highly significant amount of increase in biogas and methane production yields.

This work presents hot compressed water extraction using a continuous process to isolate lignin from plant biomass. Japanese rice straw, used as a starting material, is an agricultural by-product usually left in the field after harvest and subsequently burnt or used as animal feed. Although the Japanese rice straw also has high potential for ethanol production via fermentation process, its cellulose needs proper pretreatment for complete conversion, and lignin cannot be converted by fermentation [29, 30]. Therefore, this process was anticipated to allow for the effective removal of lignin. In addition, Converti et al. 2010 [31] suggested that vanillin could be produced from lignin-rich wastes. They explained that vanillin recovered from the sulfite spent liquor came from guaiacyl units of lignin solubilized by alkaline oxidation during softwoods pulping.

\section{Experimental Section}

\subsection{Materials}

Japanese rice straw was obtained from a Hokkaido, Japan facility jointly developed with the New Energy and Industrial Technology Development Organization (NEDO). It was shredded by a laboratory mill to a particle size of $<2 \mathrm{~mm}$ and passed through 16-mesh sieves. After this process, the sample was refrigerated at $<278 \mathrm{~K}$. The initial composition of the Japanese rice straw was cellulose $36.4 \%$, hemicellulose $25.8 \%$, lignin $12.6 \%$, and other $25.2 \%$. Distilled water obtained from a water distillation apparatus (Shibata Co., model PW-16, Japan) was used as a solvent. Lignin in powder form was obtained from Tokyo Kasei Kogyo Co. Ltd. (Japan). Xylan from beechwood and cellulose was purchased from Sigma-Aldrich Japan K. K., Tokyo, Japan. The analytical reagents used were $97 \% \mathrm{H}_{2} \mathrm{SO}_{4}$ and $99.7 \%$ methanol (Wako Pure Chemicals Industries Ltd., Japan, used as received). 


\subsection{Experimental Setup and Procedure}

A schematic diagram of the apparatus is shown in Fig. 1. This apparatus consists of a high-pressure pump, heater, reactor, thermocontrollers and back-pressure regulators (BPR). The pre-heater was fabricated from $1 / 8$ inch stainless-steel tubing (SUS316) with a volume of $50 \mathrm{~mL}$ and was heated using a mantel heater at temperatures of $443-503 \mathrm{~K}$. The $1 / 16$ inch stainless-steel tube was used to introduce the hot water from the pre-heater to the reactor that was placed in an oven. The reactor volume was $30 \mathrm{~mL}$ and was also made of stainless steel (SUS316). After the reactor inclusive of $5.0 \mathrm{~g}$ of the Japanese rice straw was installed in the system, distilled water at room temperature was pumped through the reactor inclusive pre-heater for a few minutes to purge air, completely wet the Japanese rice straw in the reactor, and pressurize the system to the set pressure of $4.0 \mathrm{MPa}$ by controlling the back-pressure regulator (BPR) monitored by pressure gauge $(\mathrm{P})$. When the system reached the desired pressure and a steady state was achieved, an electric heater was applied to heat the water. In this study, the reactor temperature was kept at $443-503 \mathrm{~K}$. Both the temperature of the pre-heater, reactor and the electric heater were measured using K-type thermocouples. The time required to heat up the reactor from room temperature to the desired temperature was $5-8 \mathrm{~min}$, after which the reactor temperature equaled the electric heater temperature. After the temperature at the reactor area reached a preset temperature, the pump was used to feed the water at 1.42, 2.92, and $4.67 \mathrm{ml}$ min $^{-1}$. During experiment, temperatures of the reactor water inlet $\left(T_{1}\right)$ and outlet $\left(T_{2}\right)$ were monitored. A profile of temperature is plotted in Fig. 2. Next, the outlet water was passed through the double-tube-type heat exchanger to quench the reaction. The time of each experiment was $60 \mathrm{~min}$; therefore, the volumes of the collected extract were 85,175 , and $280 \mathrm{~mL}$. Once the temperature in the reactor decreased to about 318 $\mathrm{K}$, cold water $(20 \mathrm{~mL})$ was pumped through the system to purge liquid remaining in the reactor. For analysis, the extracts were collected and diluted to exact volumes of 100, 200, and $300 \mathrm{~mL}$. These products were identified and quantified directly using GC-MS (gas chromatography mass spectrometry) and UV-vis spectrophotometry.

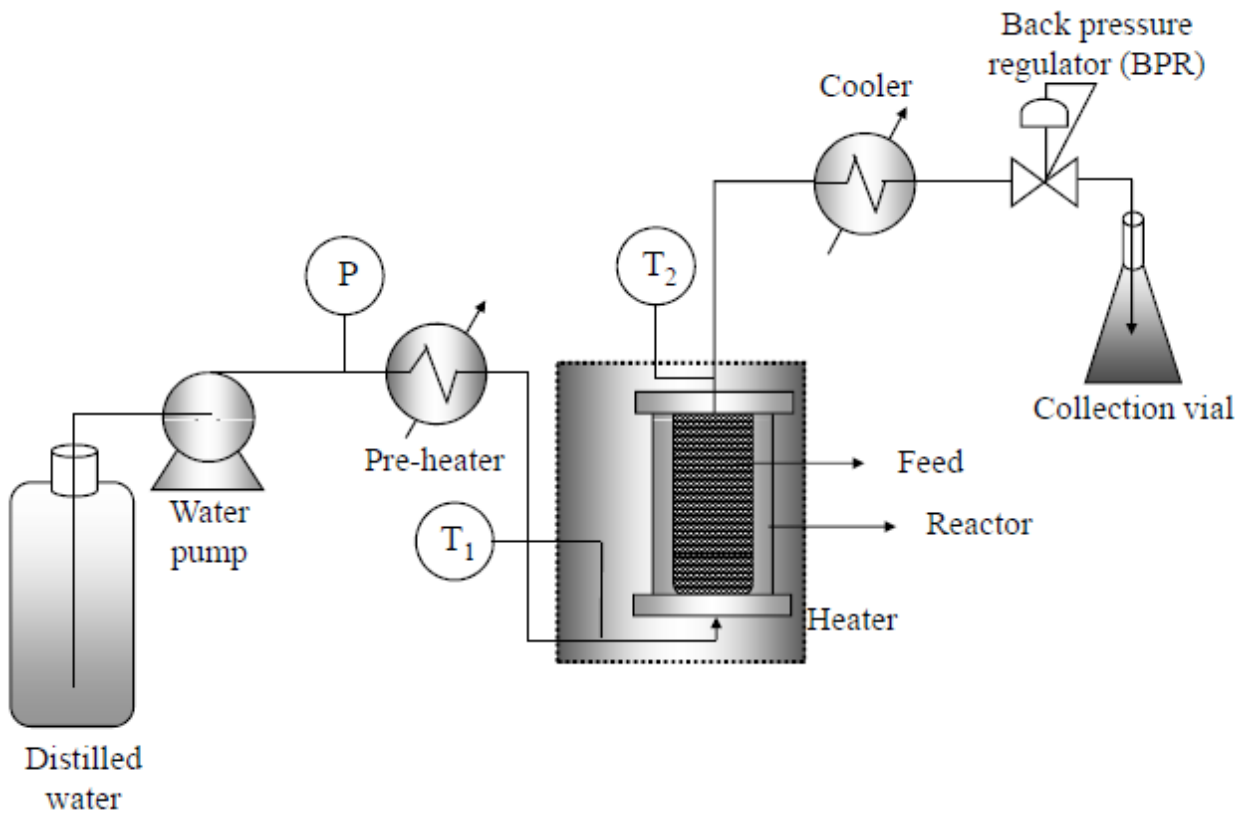

Fig. 1. Schematic diagram of hot compressed water extraction. 


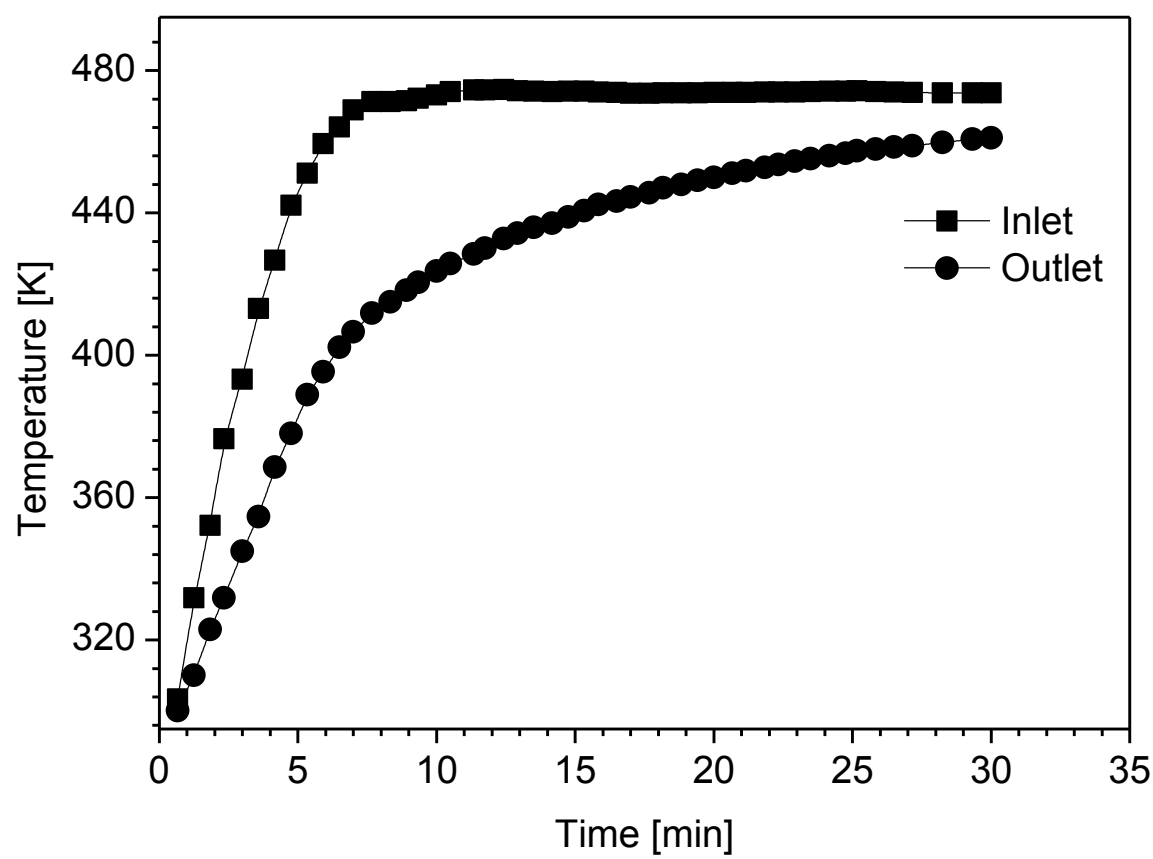

Fig. 2. Typical temperature profile for hot compressed water extraction at pressure of $4 \mathrm{MPa}$ and $2.92 \mathrm{ml}$ $\mathrm{min}^{-1}$ water flowrate.

\subsection{Analytical Methods}

Analysis of lignin content in an extracts was conducted using UV-vis spectrophotometry V-550 (Jasco Corporation, Japan). UV-vis spectra were recorded with a PC-driven scanning spectrophotometer, operating in the fast scan mode, allowing spectra of between 190 and $800 \mathrm{~nm}$ with $10 \mathrm{~nm} \mathrm{~min}{ }^{-1}$ of bands. The liquid products were analyzed in a quartz cuvette with a $1 \mathrm{~cm}$ path length. The acid soluble lignin content was determined on the hydrolysate by measuring UV-vis absorption at $205 \mathrm{~nm}$ in $1 \mathrm{~cm}$ quartz cells. It was evaluated according to Beer's law:

$$
\mathrm{A}=\varepsilon d C
$$

where $\mathrm{A}=$ absorbance; $\varepsilon=$ absorptivity $\left(\mathrm{L} \mathrm{g}^{-1} \mathrm{~cm}^{-1}\right) ; \mathrm{d}=$ path length $(1 \mathrm{~cm})$, and $C=$ concentration of lignin $\left(\mathrm{g} \mathrm{L}^{-1}\right)$. Based on the calculation, the value of extinction coefficient $(\varepsilon)$ was $110 \mathrm{~L} \mathrm{~g}^{-1} \mathrm{~cm}^{-1}$ as adopted from Dence data [32, 33]. Hence,

$$
C=\frac{\mathrm{A}}{110} D
$$

where $D=\mathrm{V}_{\mathrm{D}} / \mathrm{V}_{0} ; \mathrm{V}_{\mathrm{D}}=$ volume of diluted extract, and $\mathrm{V}_{0}=$ volume of original extract taken. The acid soluble lignin content in the extract sample was calculated as follows:

$$
\text { Lignin }[\mathrm{wt} \%]=\frac{C \times V \times 100}{1000 \times W}
$$

where $\mathrm{V}=$ total volume of the extract $[\mathrm{L}]$ and $\mathrm{W}=$ dry weight of sample $[\mathrm{g}]$.

The normal wavelength of $280 \mathrm{~nm}$ was not used because of the potential interference from furfural and hydroxymethylfurfural; these aldehydes give a sharp absorption maximum at about $280 \mathrm{~nm}$, but relatively low absorbance at shorter wavelengths. Therefore, the wavelength in the region of $200-210 \mathrm{~nm}$ provides a reasonable measure of soluble lignin in wood [34]. In addition, the liquid product was also identified by GC-MS after extraction with methanol using a GC-MS Hewlett Packard model 6890 series GC system and 5973 mass selective detector with a DB-5 MS capillary column (J\&W Scientific, length 30 m, i.d. 0.25 mm, film $0.25 \mu \mathrm{m}$ ). The GC-MS carrier gas was $\mathrm{He}$ at a flow rate of $2 \mathrm{~mL} \mathrm{~min}{ }^{-1}$. The column operating conditions were as follows: injector temperature $523 \mathrm{~K}, 1 \mu \mathrm{L}$ of a solution in methanol injected with a split ratio of 20:1. The chromatographic exit to mass spectrometer interface temperature was $573 \mathrm{~K}$. The GC oven temperature was held at $313 \mathrm{~K}$ for 0 min then programmed to increase at $5 \mathrm{~K} \mathrm{~min}^{-1}$ to $573 \mathrm{~K}$. The mass spectrometer was scanned from $\mathrm{m} / \mathrm{z} 50$ to 500 at $0.5 \mathrm{~s} \mathrm{decade}^{-1}$ of mass with an interscan interval of $0.5 \mathrm{~s}$, with the results stored as a total ion chromatogram. Electron ionization and positive ion mode were used. The NIST (National Institute of Standards and Technology) library of mass spectroscopy was used to identify the compounds. 
The solid product in water soluble extracted at each operating temperature were analyzed by a Spectrum One Fourier Transform Infrared Spectroscopy (FT-IR) spectrophotometer (Perkin-Elmer, Ltd., Bucks, England). Prior to this, vacuum evaporation at $333 \mathrm{~K}$ was used to remove water content; the products were then dried in a desiccator for 1 day at room temperature. This analysis was performed to determine the structure of the solid product after the hot compressed water extraction treatment. The samples were placed directly in the diffuse reflectance attachment sample holder between two $\mathrm{KBr}$ salt plates in a microcompression cell. Preflattening of the sample in a diamond cell was necessary prior to mounting. The spectra were measured in ATR (attenuated total reflectance) mode (golden single reflection ATR system, $\mathrm{P} / \mathrm{N} 10500$ series, Specac) at $4 \mathrm{~cm}^{-1}$ resolution. The scanning wavenumber ranged from 650 to $4000 \mathrm{~cm}^{-1}$. In addition, the ultimate analysis of solid residues remaining in the reactor was conducted using a $\mathrm{CHN}$ analyzer (Yanaco, CORDER MT-6). This analysis was carried out to determine the amount, typically a weight percent of an element in a compound. The most common type of elemental analysis is for carbon, hydrogen, and nitrogen ( $\mathrm{CHN}$ analysis). This type of analysis is especially useful for organic compounds; i.e., those compounds containing carbon-carbon bonds.

\section{Results and Discussion}

The determination of lignin, though apparently a simple matter, is one of the least satisfactory of the analyses commonly performed on plants biomass. The methods generally used involve the solution and hydrolysis of all other plant constituents and the simple assumption that the residue after such treatment is lignin. To improve on this method, this study utilized UV-vis spectrophotometry as an analysis method to capitalize on the fact that lignin absorbs UV-visible regions more strongly than cellulose or hemicellulose. UV-vis spectra of acid soluble lignin from Japanese rice straw after hot compressed water treatment at 2.79

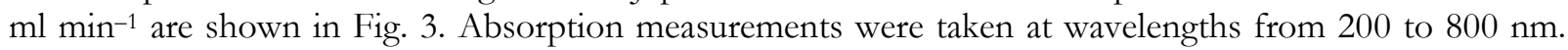
Lignin recovery was defined as the lignin concentration obtained as calculated from the division of the absorbance derived from the absorptivity as per equation (1) with the initial concentration of lignin fed into the reactor. Essentially, this method relies on determining UV absorption of the final diluted acid solution of the Klason lignin procedure. According to Hatfield et al. 2005 [32] indicated that a considerable portion of the total lignin is soluble after the acid treatment and that the amount of insoluble residue is relatively insignificant in the measure of lignin content; therefore, the total lignin content was determined as insoluble Klason lignin plus the ultraviolet-estimated acid-soluble lignin. This figure shows two predominant peaks in this wavelength region, the first at 200-210 nm and the second at 270-290 nm; UV absorption between 270 and $290 \mathrm{~nm}$ is an indicator of aldehyde groups such as furfural and hydroxymethylfurfural, which form from carbohydrates during the acid hydrolysis. Consequently, as explained before, the UV absorption of the acid soluble lignin was measured at wavelength 200-210 nm. Wegener et al. 1983 [35] reported that the UV absorption maximum of acid soluble lignin samples near $200 \mathrm{~nm}$ can be recorded exactly and evaluated quantitatively. At around $200 \mathrm{~nm}$, the UV transmittance properties was high without interference from the degradation products of polysaccharides. Maekawa et al. 1989 [36] concluded that the UV absorption between $200-210 \mathrm{~nm}$ is the preferred wavelength for measuring the absorbance of acid soluble lignin from hardwoods, softwoods, and bamboo. Jahan \& Mun 2007 [37] also explained that due to the lignin molecule contains no large portion of unsaturated aliphatic units in addition to its aromatic structure, it is concluded that there are the two characteristic bands in the lignin spectrum at 200-230 and 260-280 nm. However, due to common acidic degradation products of carbohydrates which have absorbance maximums at around $280 \mathrm{~nm}$, the measurement wavelength at around $205 \mathrm{~nm}$ is the better choice. They also explained that the absorbance of UV spectra at around $205 \mathrm{~nm}$ was directly proportional to the purity level of lignin. 


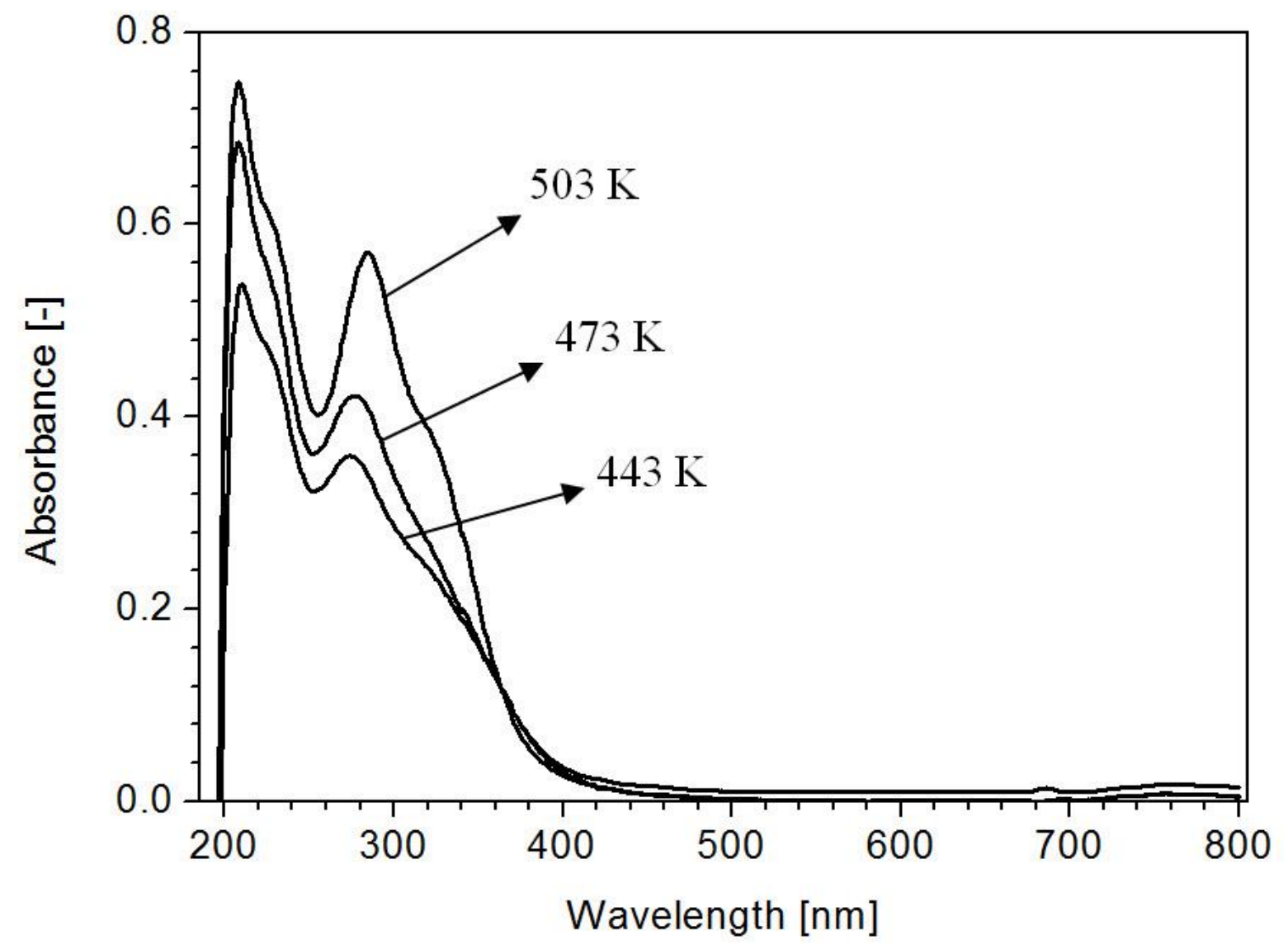

Fig. 3. UV-vis spectra of water soluble an extraction products.

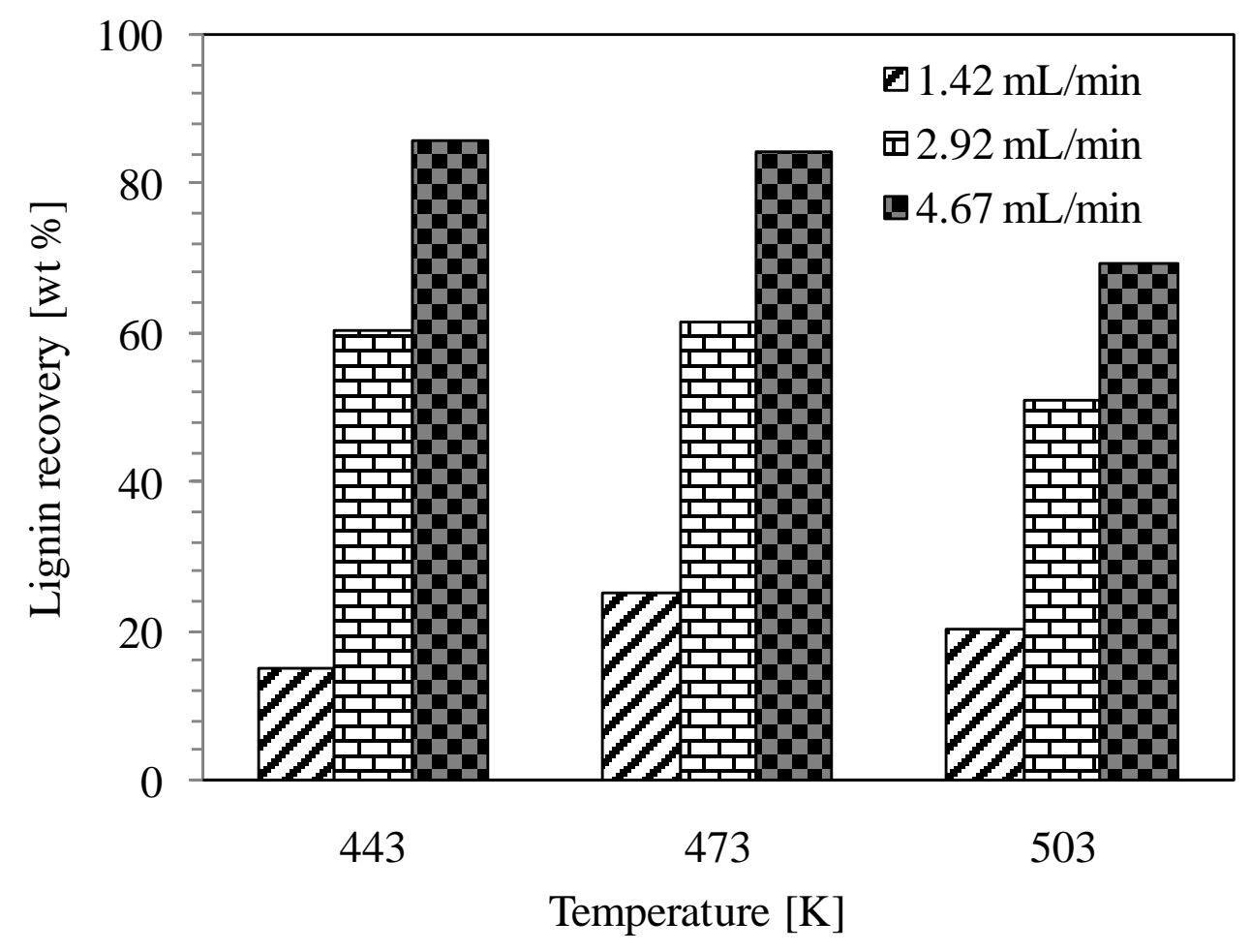

Fig. 4. Amount of lignin removal by hot compressed water from Japanese rice straw. 
That covalent linkages between lignin and carbohydrates exist in wood is well-known. In the fractionation of plant biomass by hot compressed water, their separation is very important for complete and efficient utilization of substances which compose cell walls of plant biomass. The presence of water as the reactant leads to hydrolysis reaction and cleavage of bonds between hetero-atoms and carbon atoms. Non-requirement of additional chemicals and lower fabrication costs make this system attractive. Minowa $e t$ al. 1998 [38] reported that the decomposition of biomass components start at around $473 \mathrm{~K}$ or higher. Ko et al. 2014 [39] also investigated the fate of the lignin content in a hardwood biomass after treatment by liquid hot water at temperatures of 453-493 K. They reported that the percentage of lignin increased from 29.3 to $40.3 \%$ with increasing treatment temperature. They also explained that the higher treatment temperature $(493 \mathrm{~K})$ led to an increase in lignin recovery yield, which might be caused by the condensation reactions of lignin with other degradation products. Therefore, isolation of lignin is also possible at these range temperatures using hot compressed water. The amount of lignin from Japanese rice straw extracted by hot compressed water at a pressure of $4 \mathrm{MPa}$ is shown in Fig. 4. Lignin recovery approached $85 \%$ when the extraction was performed at 443 and $473 \mathrm{~K}$ with a flow rate of $4.67 \mathrm{ml} \mathrm{min}^{-1}$. The lignin extraction rate increased with increased flow rate at each temperature; the increased flow rate allowed the dissolved lignin to be swept from the reactor before it could react and precipitate, resulting in substantially higher lignin removal [40, 41]. Under the same conditions, the recovery of lignin decreased at $503 \mathrm{~K}$, possibly explicable by cleavage of ether and $\mathrm{C}-\mathrm{C}$ linkages as functional groups in the trans-p-coumaryl alcohol, coniferyl alcohol and sinapyl alcohol existing in lignin structure units [29, 30, 42]. Demirbas et al. 2000 [36] reported that lignin is broken down by extensive cleavage of $\beta$-aryl ether linkages during steaming of wood at temperatures under $488 \mathrm{~K}$. They explained that normal $\mathrm{C}-\mathrm{C}$ bond energy is about $380 \mathrm{~kJ} \mathrm{~mol}^{-1}$ and thermal excitation of the molecules becomes sufficient to break these bonds. These bonds, particularly the $\mathrm{O}-\mathrm{O}$ bonds, are exceptionally weak and therefore can break at lower temperatures. Toor et al. 2011 [30] also explained that during hydrothermal degradation various phenols and methoxy phenols are formed by hydrolysis of ether-bonds (O-O bonds).

Table 1. Comparisons of different lignin extraction methods .

\begin{tabular}{|c|c|c|c|c|}
\hline Material & Process & Condition & $\begin{array}{l}\text { Yield } \\
{\left[w t^{0} \%\right]}\end{array}$ & Literature \\
\hline Mixed hardwood & Liquid hot water & $\begin{array}{l}453-493 \mathrm{~K} ; 10- \\
15 \mathrm{~min}\end{array}$ & $\begin{array}{l}81.8- \\
97.4\end{array}$ & $\begin{array}{l}\text { Ko et al. } 2014 \\
{[39]}\end{array}$ \\
\hline $\begin{array}{l}\text { Air-dried bio-ethanol } \\
\text { production residue }\end{array}$ & Solvothermal & $\begin{array}{l}323-483 \mathrm{~K} ; 15- \\
120 \mathrm{~min}\end{array}$ & $\begin{array}{l}41.60- \\
74.14\end{array}$ & $\begin{array}{l}\text { Guo et al. } 2013 \\
\text { [43] }\end{array}$ \\
\hline Flax shives & $\begin{array}{l}\text { High temperature and } \\
\text { high pressure }\end{array}$ & $\begin{array}{l}493 \mathrm{~K} ; 5.2 \mathrm{MPa} \text {, } \\
130 \mathrm{~min}\end{array}$ & 26.0 & $\begin{array}{l}\text { Buranov et al. } \\
2010 \text { [44] }\end{array}$ \\
\hline $\begin{array}{l}\text { Bamboo (Neosinocalamus } \\
\text { affinis) }\end{array}$ & Ultrasonic cell crusher & $293 \mathrm{~K} ; 0-50 \mathrm{~min}$ & $\begin{array}{l}13.4- \\
16.4\end{array}$ & $\begin{array}{l}\text { Li et al. } 2010 \\
{[45]}\end{array}$ \\
\hline Maple wood flour & Ionic liquid solvent & $263 \mathrm{~K} ; 0.5-70 \mathrm{~h}$ & 16-86 & $\begin{array}{l}\text { Lee } \text { et al. } 2009 \\
\text { [46] }\end{array}$ \\
\hline $\begin{array}{l}\text { Wheat straw (Variety } \\
\text { Riband) }\end{array}$ & Ultrasonic irradiation & $308 \mathrm{~K} ; 0-35 \mathrm{~min}$ & $\begin{array}{l}43.3- \\
46.2\end{array}$ & $\begin{array}{l}\text { Sun et al. } 2002 \\
\text { [47] }\end{array}$ \\
\hline $\begin{array}{l}\text { Wheat straw (Variety } \\
\text { Riband) }\end{array}$ & Ultrasonic irradiation & $333 \mathrm{~K} ; 0-35 \mathrm{~min}$ & $\begin{array}{l}67.4- \\
78.5 \\
\end{array}$ & $\begin{array}{l}\text { Sun et al. } 2002 \\
{[48]}\end{array}$ \\
\hline
\end{tabular}

As introduced in introduction section that wood biomass consists of cellulose (40 45 $\mathrm{wt} \%$ ), hemicellulose $(25 \sim 35 \mathrm{wt} \%)$ and lignin $(15 \sim 30 \mathrm{wt} \%)$ as main components. This causes that wood biomass in general become attractive feedstock because of high polysaccharide content; however, it is not easy to use this biomass resources for ethanol and other chemicals production. Fractionation is often considered a pre-treatment process, prior to produce its biomass components. As shown in Table 1, there are several methods for performing the biomass fractionation especially to isolate lignin. However, the extraction methods are not easy to apply into large scale production due to the high cost or complex process. Sun $e t$ al. 2002 [48] conducted ultrasound-assisted extraction of wheat straw lignin in alkaline organosolv medium. They reported that applying sonication for 5-35 min resulted in an increasing yield of lignin by 61.0-78.5 of the original lignin in wheat straw. They said that the current results revealed that ultrasonic irradiation had a 
significant effect on the delignification of wheat straw. Lee et al. 2009 [46] performed wood flour fractionation by using ionic liquids as pretreatment solvents to extract lignin from wood flour. They reported that ionic liquid such as $[\mathrm{Emim}]\left[\mathrm{CH}_{3} \mathrm{COO}\right]$ did not dissolve the wood flour; conversely, facile extraction of the lignin was achieved. However, ionic liquid pretreatment also would result in a substantial decrease in the crystallinity of the cellulose. In other words, they demonstrated that the wood flour underwent delignification with substantially smaller losses of cellulose and xylan upon pretreatment in [Emim] [ $\left.\mathrm{CH}_{3} \mathrm{COO}\right]$. Guo et al. 2013 [43] developed an adequate method to separate lignin from air-dried bio-ethanol production residue by using solvothermal methods. Benzyl alcohol, dioxane and ethanol were used as lignin solvent extraction at temperature of 323-443 K with 5-120 min reaction time. They concluded that benzyl alcohol and dioxane extraction could reach higher lignin yield of 71.55 and $74.14 \%$ when the experiments were conducted at $443 \mathrm{~K}$ and $323 \mathrm{~K}$ with reaction time 15 and 60 min reaction time, respectively. They explained that that the chemical components and structure of lignin extracted by benzyl alcohol or dioxane was similar to that of lignin obtained with alkali-solution and acid-isolation method. Recently, Ko et al. 2014 [39] conducted experiments to remove lignin and its derived mixed hardwoods by liquid hot water at different severities. They reported that the isolated lignin from mixed hardwoods was $97.4 \%$ at $493 \mathrm{~K}$ with $15 \mathrm{~min}$ reaction time. In comparison with other methods (see Table 1), our work, hot compressed water extraction is simpler and could extract lignin around $85 \%$ from Japanese rice straw. Here, the Japanese rice straw was directly fed in the extraction reactor as the starting material without any treatments. Under these conditions, water-soluble compounds (lignin) could be extracted from Japanese rice straw via autohydrolysis [15-17]. It could be said that this process is simple and versatile technique because of its capability and feasibility in the separation of large quantities of biomass.

In order to identify the monomer derived from treatment of Japanese rice straw by hot compressed water, the collected aqueous effluent was diluted with methanol prior to analysis using GC-MS, a method which is well-known as a powerful tool to identify aromatic and aliphatic compounds. The identities of those compounds determined through a match of mass spectra in the GC-MS computer library, which contains a wide range of organic compounds, are reliable. Extraction with methanol gave organic compounds shown in Fig. 5, a typical GC-MS chromatogram of the products obtained at $443 \mathrm{~K}, 473 \mathrm{~K}$, and $503 \mathrm{~K}$ with $2.92 \mathrm{ml} \mathrm{min}{ }^{-1}$ flow rate. It was well known that one of the most important parameters affecting hot compressed water extraction efficiencies is the extraction temperature. As the temperature increased, it was obviously decrease in dielectric constant, an increase in the diffusion rate and a decrease in the viscosity and surface tension. It should be noted that increasing the extraction temperature above a certain value also gives increase to the degradation of the extract components. In the case of hot compressed water extraction flow rate, only $2.92 \mathrm{ml} \mathrm{min}^{-1}$ flow rate was presented. This condition was selected on the basis of the previous researcher's reports [49, 50]. Rangsriwong et al. 2009 [49] reported that the various extraction flow rates should affect the extraction rate but not the total amounts of the compounds extracted in the process. An increase in flow rate, it means that the mass transfer of the compounds extracted from the surface of the solid phase into the water phase regulated most of the extraction process. Increase in flow rate resulted in increase in superficial velocity, and thus, quicker mass transfer. As shown in Fig. 5, most of these compounds have been identified as lignin-derived compounds, sugar-derived compounds, and nitrogen-containing compounds. The lignin-derived compounds were clearly detected [51-53]. Klinke et al. 2002 [51] reported on a wide variety of phenolic compounds derived from alkaline wet oxidation of wheat straw at $458 \mathrm{~K}$ or $468 \mathrm{~K}$ with a pressure of 11-12 bar, vanillic acid and vanillin being the major components, followed by 4-hydroxybenzaldehyde, syringaldehyde, syringic acid, coumaric acid and guaiacol. However, the sugar-derived compounds detected by GC-MS increased with increased reaction temperature ( $473 \mathrm{~K}$ and $503 \mathrm{~K}$ ). This phenomenon is most probably due to the partial degradation of cellulose at higher extraction temperatures. Yuan et al. 2009 [54] investigated the content of bio-oil obtained from the thermochemical liquefaction of straw by hot compressed water at temperature of $473-583 \mathrm{~K}$. They reported that the bio-oil, a complex mixture containing carbon, hydrogen, and oxygen, is composed of acids, alcohols, aldehydes, esters, ketones, lignin derived phenols, and extractible terpene with multifunctional groups. The main compounds in those six samples were dibutyl phthalate and butylated hydroxytoluene, which is might be formed by the decomposition of lignin functional groups with some side reactions during the hydrothermal treatment. At $473 \mathrm{~K}$, the main compounds in bio-oil obtained were butylated hydroxytoluene, dibutyl phthalate, and 1,2-benzenedicarboxylic acid, butyl 2-ethylhexyl ester. Similar to our result, when the temperature increased to 523, the composition of the oil became more complex, many high molecular compounds were produced as well, such as phorbol, 4-hydroxy octadecanoic acid methyl ester, and 17-pentatriacontene. Table 2 lists the data concerning the 
compositional analysis under each experimental condition. Tymchyshyn and Xu 2010 [52] also reported that the oil derived from the liquefaction of lignin was the most concentrated with phenolic compounds. They explained that it is not surprising that the major compounds produced by the liquefaction of sawdust at around $523 \mathrm{~K}$ were phenolic compounds such as 2-methoxyphenol, 2-methoxy-4-methylphenol and 4ethyl-2-methoxyphenol which comprise almost the phenolic/neutral oil. The major components of the phenolic/neutral oils derived from cornstalks are more varied. They said that substituted phenols and phenolic compounds comprise almost $74 \%$ of the phenolic/neutral oil collected from the liquefaction of lignin. In the case of cellulose, the major components of the cellulose-derived oil appeared to be esters of complex organic acids and long chain hydrocarbons, likely formed by dehydration of the cellulose.

Further, it could be said that cellulose, hemicellulose, and lignin as main components of Japanese rice straw underwent decomposition simultaneously during hot compressed water extraction process. Under these conditions, the cellulose degrades to low molecular weight aldehydes and ketones, then these aldehydes and ketones may then form aromatic compounds by condensation and dehydration. Hemicelluloses are also easily solubilized and hydrolyzed into various monosaccharides, including xylose, mannose, glucose and galactose, in water. As well as cellulose and hemicellulose, the decomposition of lignin was also occurred. It would be decomposed into various phenols and methoxy phenols by hydrolysis of ether-bonds during hot compressed water extraction. In this work, the reaction mechanism of cellulose, hemicellulose, and lignin are not presented.

The chemical structure of Japanese rice straw as a starting material and its major constituents, cellulose, xylan (hemicellulose) and lignin, were analyzed using FT-IR direct transmittance through $\mathrm{KBr}$ pellet technique. Infrared spectroscopy is an analytical technique that allows identification of unknown substances and of the types of chemical bonds the compounds in those substances contain. Rana et al. 2010 [55] explained that most of the observed peaks of wood represent major cell wall components such as cellulose at around 1154 and $898 \mathrm{~cm}^{-1}$; hemicelluloses at around 1738, 1024, 1057, and $1090 \mathrm{~cm}^{-1}$; and lignin at around 1596, 1505, and $1270 \mathrm{~cm}^{-1}$. FT-IR spectra of Japanese rice straw, cellulose, xylan, and lignin are shown in Fig. 6 (a). It can be observed that cellulose, xylan and lignin as three components of biomass most likely consist of alkene, esters, aromatics, ketone and alcohol, with different oxygen-containing functional groups observed $[4,42,50,56]$. As a reference, the peak positions of all infrared bands and their functional groups are summarized in Table 3. Each molecule is composed of many different chemical bonds, and these bonds are slightly elastic and can stretch, bend, or vibrate. Therefore, some differences exist at each FT-IR spectra due to their structure properties. The intensity of the absorbance due to the hydrogen bonded $\mathrm{O}-\mathrm{H}$ stretching $\left(3600-3000 \mathrm{~cm}^{-1}\right)$ could be found in each component. Strong IR spectra of $\mathrm{C}-\mathrm{O}$ and $\mathrm{C}=\mathrm{O}$ were found in lignin and xylan, while cellulose contained only high $\mathrm{C}-\mathrm{O}$ compounds. At the region 1800-700 $\mathrm{cm}^{-1}$, the IR spectra of lignin had high absorbance due to the presence of compounds containing methoxyl-O- $-\mathrm{CH}_{3}, \mathrm{C}-\mathrm{O}-\mathrm{C}$ stretching and $\mathrm{C}=\mathrm{C}$ stretching (aromatic ring). Fig. 6 (b) shows the spectra for lignin and solid products from hot compressed water treatment at 443, 473, and $503 \mathrm{~K}$, respectively. The peaks that point down represent the frequencies of light that the molecules absorb. Each spectrum is a spectral average of at least four scans. Most bands showed a shift in wave number for different solid products. The bands in the 3336.2-3356.9 and $2850.3-2937.7 \mathrm{~cm}^{-1}$ region were assigned to the hydrogen bonded $\mathrm{O}-\mathrm{H}$ stretching and $\mathrm{C}-\mathrm{Hn}$ stretching groups, respectively. In these regions, the peaks in (a) - (d) were clearly observed. As mentioned above, the fingerprint at the region $1800-700 \mathrm{~cm}^{-1}$, indicating compounds rich in methoxyl-O- $\mathrm{CH}_{3}, \mathrm{C}-\mathrm{O}-\mathrm{C}$ stretching and $\mathrm{C}=\mathrm{C}$ stretching (aromatic ring), were also found at each solid product. These aromatic skeleton vibrations at around 1600, 1515 and 1426 $\mathrm{cm}^{-1}$ and the C-H deformation combined with aromatic ring vibration at $1462 \mathrm{~cm}^{-1}$ are common for all lignins, although the intensity of the bands may differ. In detail, Boeriu et al. 2004 [57] reported that common for the spectra of all lignins are a weak band at $1370-1375 \mathrm{~cm}^{-1}$ originating from phenolic $\mathrm{OH}$ and aliphatic $\mathrm{C}-\mathrm{H}$ in methyl groups and a strong vibration at $1215-1220 \mathrm{~cm}^{-1}$ that can be associated with $\mathrm{C}-\mathrm{C}$ plus $\mathrm{C}-\mathrm{O}$ plus $\mathrm{C}=\mathrm{O}$ stretching. Respect to lignin and sugar content in the samples and the amount of hydroxyl and carboxyl groups, they used the lignin content of samples varied between 64 and $99 \%$. The aromatic $\mathrm{C}-\mathrm{H}$ deformation at $1035 \mathrm{~cm}^{-1}$ appears as a complex vibration associated with the $\mathrm{C}-\mathrm{O}, \mathrm{C}-\mathrm{C}$ stretching and $\mathrm{C}-\mathrm{OH}$ bending in polysaccharides. Carbohydrate originating vibrations are associated also with other vibrations in the spectral region $1000-1300 \mathrm{~cm}^{-1}$. The influence of polysaccharide impurities on the spectral profile is most visible for solid products when the extraction was conducted at higher temperature. As shown in Fig. 6(b), the spectral characteristics of the lignin and solid products are essentially the same, indicating that the three kinds of solid products obtained by hot compressed water extraction are within a similar functional group as lignin. However, the apparent difference between the 
intensity of absorbances were found. It might be due to the loss of aliphatic and aromatic functional groups since further degradation occurs at higher temperatures. Ko et al. 2014 [39] reported that the intensity of isolated lignin functional groups decreased with increasing the pretreatment temperatures. The greater hydrolysis of isolated lignin functional groups at higher pretreatment temperatures can be attributed to the degradation of aromatic rings and breakage of ether linkages. Nevertheless, Yuan et al. 2009 [54] suggested that the main component including cellulose and hemicellulose of straw began to decompose at $473 \mathrm{~K}$, but the lignin decomposed at 523-573 K. Judging from the results, it could be said that these range temperatures (443-503) are suitable to extract lignin from Japanese rice straw.
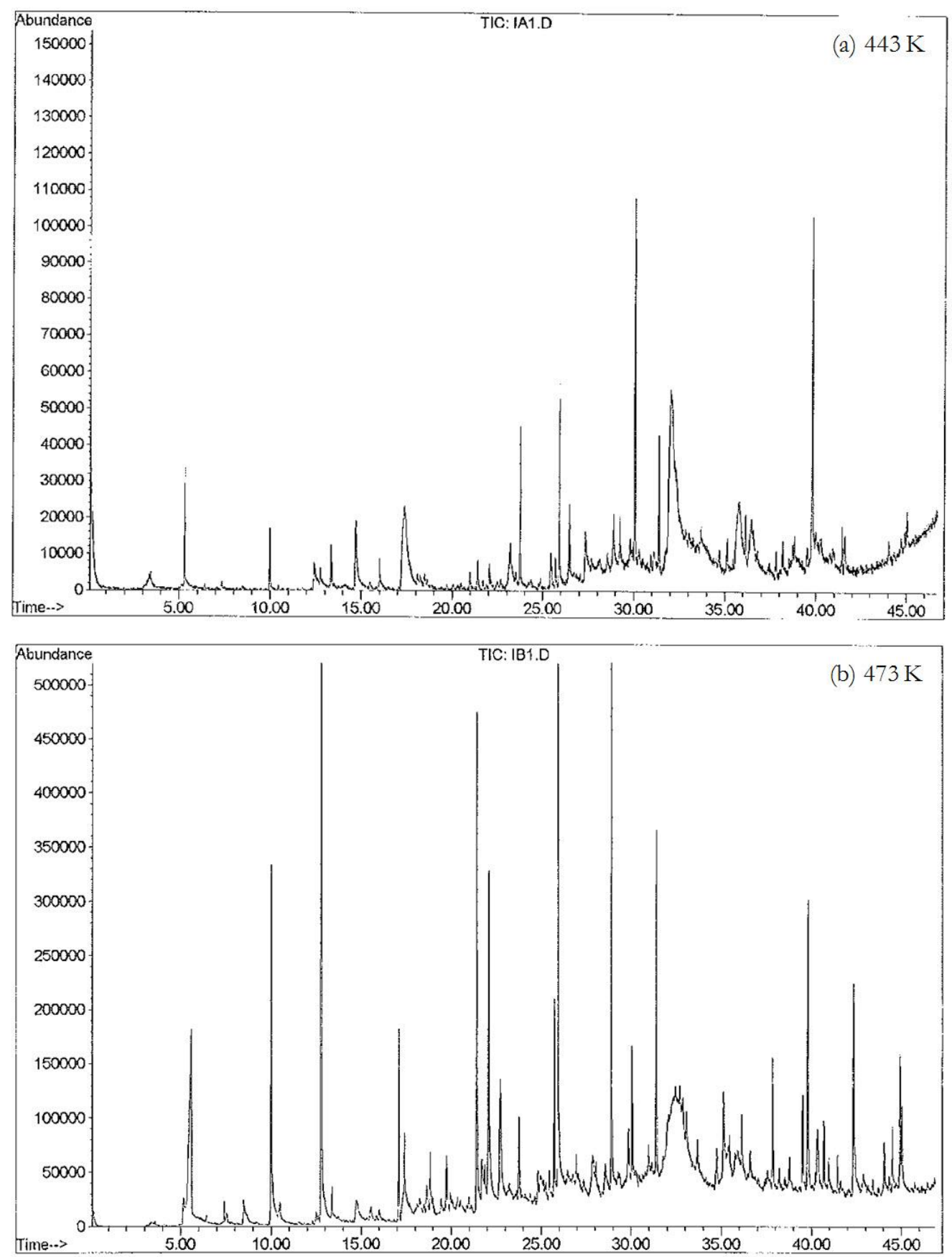


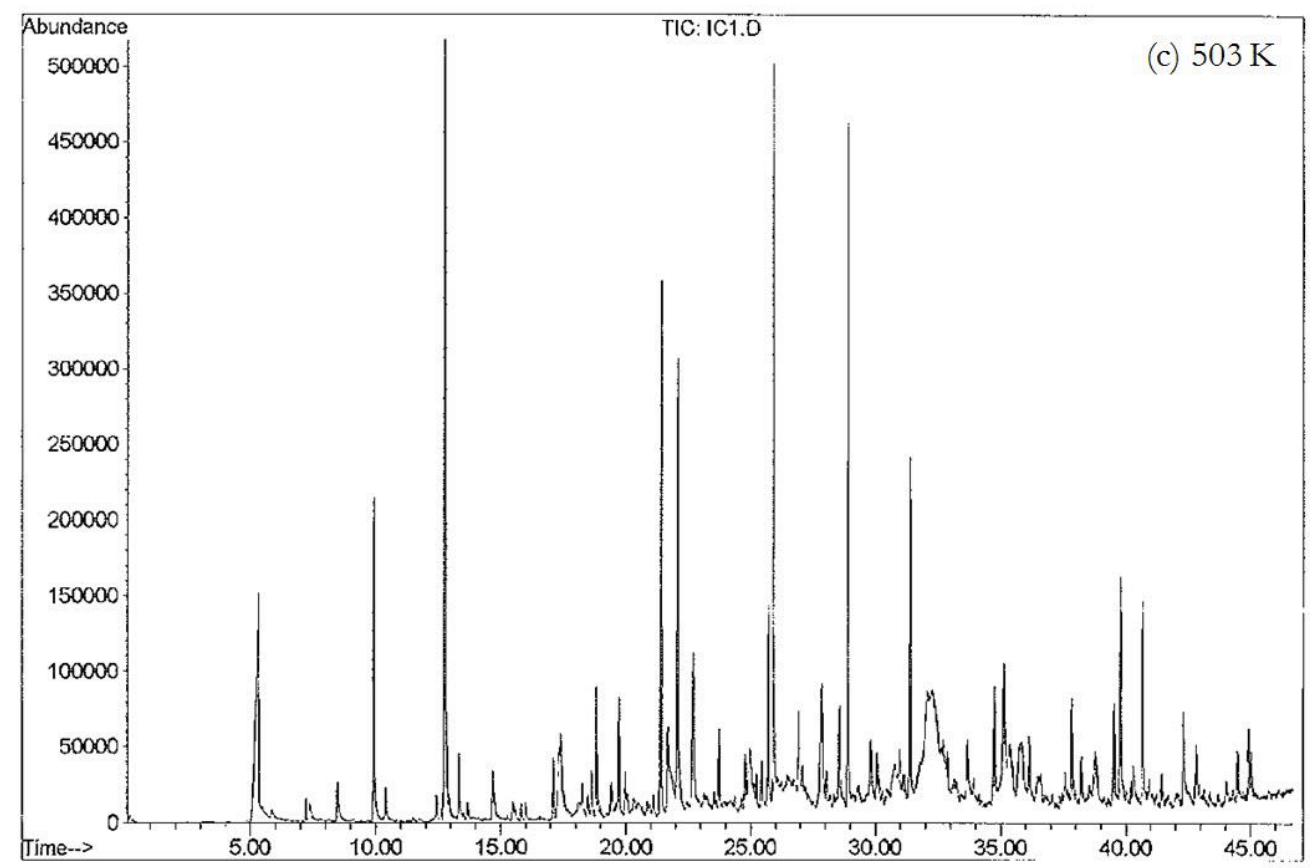

Fig. 5. GC-MS chromatogram of water soluble products recovered after treatment at (a) 443, (b) 473,

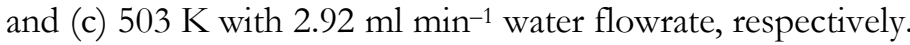

Table 2(a). List of GC-MS monomeric products in the water soluble fraction at temperature of $443 \mathrm{~K}$ with $2.92 \mathrm{ml} \mathrm{min}^{-1}$ water flowrate.

\begin{tabular}{cclcc}
\hline No & $\begin{array}{c}\text { Retention } \\
\text { time }[\mathrm{min}]\end{array}$ & \multicolumn{1}{c}{ Compound name } & $\begin{array}{c}\text { Molecular } \\
\text { weight }\end{array}$ & Compound formula \\
\hline 1 & 5.32 & Urea & 60.06 & $\mathrm{CH}_{4} \mathrm{~N}_{2} \mathrm{O}$ \\
2 & 9.98 & 3-Methylbutanal & 86.13 & $\mathrm{C}_{5} \mathrm{H}_{10} \mathrm{O}$ \\
3 & 12.46 & Methyl nitrite & 61.04 & $\mathrm{CH}_{3} \mathrm{NO}_{2}$ \\
4 & 12.76 & 2-Furancarboxaldehyde & 96.08 & $\mathrm{C}_{5} \mathrm{H}_{4} \mathrm{O}_{2}$ \\
5 & 13.35 & 2,5-Dihydro-3,4-dimethylfuran & 98.14 & $\mathrm{C}_{6} \mathrm{H}_{10} \mathrm{O}$ \\
6 & 14.72 & Methylhydrazone acetaldehyde & 72.11 & $\mathrm{C}_{3} \mathrm{H}_{8} \mathrm{~N}_{2}$ \\
7 & 16.02 & 2,3-Dihydro-5-methyl-2-furanone & 98.10 & $\mathrm{C}_{5} \mathrm{H}_{6} \mathrm{O}_{2}$ \\
8 & 17.36 & Glycerin & 92.1 & $\mathrm{C}_{3} \mathrm{H}_{8} \mathrm{O}_{3}$ \\
9 & 18.24 & Allyl alcohol & 58.08 & $\mathrm{C}_{3} \mathrm{H}_{6} \mathrm{O}$ \\
10 & 18.11 & N-Methyloxazolidone & 101.10 & $\mathrm{C}_{4} \mathrm{H}_{7} \mathrm{NO}_{2}$ \\
11 & 18.49 & Dihydropyran & 84.12 & $\mathrm{C}_{5} \mathrm{H}_{8} \mathrm{O}$ \\
12 & 20.99 & Maltol & 126.11 & $\mathrm{C}_{6} \mathrm{H}_{6} \mathrm{O}_{3}$ \\
13 & 21.41 & 2-Nitro-2-butene & 101.10 & $\mathrm{C}_{4} \mathrm{H}_{7} \mathrm{NO}_{2}$ \\
14 & 22.05 & 2-Cyclohexenone & 96.13 & $\mathrm{C}_{6} \mathrm{H}_{8} \mathrm{O}$ \\
15 & 23.18 & Sec-butylamine & 73.14 & $\mathrm{C}_{4} \mathrm{H}_{11} \mathrm{~N}$ \\
16 & 23.74 & 3-Hydroxy-2,3-dihydromaltol & 144.13 & $\mathrm{C}_{6} \mathrm{H}_{8} \mathrm{O}_{4}$ \\
17 & 25.46 & 2,4-Dimethylhexane & 114.23 & $\mathrm{C}_{8} \mathrm{H}_{18}$ \\
18 & 25.91 & 5-Hydrxoymethylfurfural & 126.11 & $\mathrm{C}_{6} \mathrm{H}_{6} \mathrm{O}_{3}$ \\
19 & 26.46 & Tetrahydro-3,4-furandiol & 104.11 & $\mathrm{C}_{4} \mathrm{H}_{8} \mathrm{O}_{3}$ \\
20 & 27.35 & 1,2-Heptanediol & 132.20 & $\mathrm{C}_{7} \mathrm{H}_{16} \mathrm{O}_{2}$ \\
21 & 28.87 & Durenol & 150.22 & $\mathrm{C}_{10} \mathrm{H}_{14} \mathrm{O}$ \\
22 & 29.24 & 1,1-Diethoxydecane & 230.39 & $\mathrm{C}_{14} \mathrm{H}_{30} \mathrm{O}_{2}$ \\
& & & &
\end{tabular}




\begin{tabular}{lllcc}
23 & 30.06 & Eugenol & 164.20 & $\mathrm{C}_{10} \mathrm{H}_{12} \mathrm{O}_{2}$ \\
24 & 31.37 & Vanillin & 152.15 & $\mathrm{C}_{8} \mathrm{H}_{8} \mathrm{O}_{3}$ \\
25 & 32.01 & Butyl glycolate & 132.1577 & $\mathrm{C}_{6} \mathrm{H}_{12} \mathrm{O}_{3}$ \\
26 & 35.73 & Methyl 2,2-dimethylvalerate & 144.21 & $\mathrm{C}_{8} \mathrm{H}_{16} \mathrm{O}_{2}$ \\
27 & 36.45 & Octadecanol acetate & 312.53 & $\mathrm{C} 20 \mathrm{H} 40 \mathrm{O} 2$ \\
\hline
\end{tabular}

Table 2(b). List of GC-MS monomeric products in the water soluble fraction at temperature of $473 \mathrm{~K}$ with $2.92 \mathrm{ml} \mathrm{min}^{-1}$ water flowrate.

\begin{tabular}{|c|c|c|c|c|}
\hline No & $\begin{array}{l}\text { Retention } \\
\text { time [min] }\end{array}$ & Compound name & $\begin{array}{c}\text { Molecular } \\
\text { weight }\end{array}$ & Compound formula \\
\hline 1 & 5.59 & Urea & 60.06 & $\mathrm{CH}_{4} \mathrm{~N}_{2} \mathrm{O}$ \\
\hline 2 & 8.53 & Dicyclomine & 309.49 & $\mathrm{C}_{19} \mathrm{H}_{35} \mathrm{NO}_{2}$ \\
\hline 3 & 10.01 & 3-Methylbutanal & 86.13 & $\mathrm{C}_{5} \mathrm{H}_{10} \mathrm{O}$ \\
\hline 4 & 12.76 & 2-Furancarboxaldehyde & 96.08 & $\mathrm{C}_{5} \mathrm{H}_{4} \mathrm{O}_{2}$ \\
\hline 5 & 17.10 & Trimethyloxazole & 111.14 & $\mathrm{C}_{6} \mathrm{H}_{9} \mathrm{NO}$ \\
\hline 6 & 17.41 & 5-Methyl-2-furaldehyde & 110.11 & $\mathrm{C}_{6} \mathrm{H}_{6} \mathrm{O}_{2}$ \\
\hline 7 & 18.83 & 2,4-Imidazolidinedione & 114.10 & $\mathrm{C}_{4} \mathrm{H}_{6} \mathrm{~N}_{2} \mathrm{O}_{2}$ \\
\hline 8 & 21.42 & N-Ethylpropanamide & 101.15 & $\mathrm{C}_{5} \mathrm{H}_{11} \mathrm{NO}$ \\
\hline 9 & 22.07 & Furan & 68.07 & $\mathrm{C}_{4} \mathrm{H}_{4} \mathrm{O}$ \\
\hline 10 & 23.74 & 3-Hydroxy-2,3-dihydromaltol & 144.13 & $\mathrm{C}_{6} \mathrm{H}_{8} \mathrm{O}_{4}$ \\
\hline 11 & 25.71 & Dihydrobenzofuran & 120.15 & $\mathrm{C}_{8} \mathrm{H}_{8} \mathrm{O}$ \\
\hline 12 & 25.92 & 5-Hydrxoymethylfurfural & 126.11 & $\mathrm{C}_{6} \mathrm{H}_{6} \mathrm{O}_{3}$ \\
\hline 13 & 28.89 & 2,4,6-Trimethyl-m-phenylenediamine & 150.22 & $\mathrm{C}_{9} \mathrm{H}_{14} \mathrm{~N}_{2}$ \\
\hline 14 & 30.06 & Eugenol & 164.20 & $\mathrm{C}_{10} \mathrm{H}_{12} \mathrm{O}_{2}$ \\
\hline 15 & 31.37 & Vanillin & 152.15 & $\mathrm{C}_{8} \mathrm{H}_{8} \mathrm{O}_{3}$ \\
\hline 16 & 32.07 & D-Arabinose & 150.16 & $\mathrm{C}_{5} \mathrm{H}_{10} \mathrm{O}_{5}$ \\
\hline 17 & 32.28 & D-Galactose & 180.16 & $\mathrm{C}_{6} \mathrm{H}_{12} \mathrm{O}_{6}$ \\
\hline 18 & 35.12 & Vanillic acid & 168.15 & $\mathrm{C}_{8} \mathrm{H}_{8} \mathrm{O}_{4}$ \\
\hline 19 & 37.82 & Syringaldehyde & 182.17 & $\mathrm{C}_{9} \mathrm{H}_{10} \mathrm{O}_{4}$ \\
\hline 20 & 39.51 & Homovanillic acid methyl ester & 196.20 & $\mathrm{C}_{10} \mathrm{H}_{12} \mathrm{O}_{4}$ \\
\hline 21 & 39.77 & Eugenol methyl ether & 178.23 & $\mathrm{C}_{11} \mathrm{H}_{14} \mathrm{O}_{2}$ \\
\hline 22 & 40.67 & 1-Phenyl-1H-indene & 192.26 & $\mathrm{C}_{15} \mathrm{H}_{12}$ \\
\hline 23 & 42.31 & 3-Methoxy-4-hydroxycinnamic acid & 194.18 & $\mathrm{C}_{10} \mathrm{H}_{10} \mathrm{O}_{4}$ \\
\hline 24 & 44.48 & Methyl diphenylacetate & 226.27 & $\mathrm{C}_{15} \mathrm{H}_{14} \mathrm{O}_{2}$ \\
\hline 24 & 44.91 & 4-allyl-1,2,6-trimethoxybenzene & 208.25 & $\mathrm{C}_{12} \mathrm{H}_{16} \mathrm{O}_{3}$ \\
\hline 26 & 45.03 & $\begin{array}{l}\text { 4b,10a- } \\
\text { Dihydrobenzo[3,4] cyclobuta[1,2- } \\
\text { b][1,4]benzodioxine }\end{array}$ & 210.23 & $\mathrm{C}_{14} \mathrm{H}_{10} \mathrm{O}_{2}$ \\
\hline
\end{tabular}

Table 2(c). List of GC-MS monomeric products in the water soluble fraction at temperature of $503 \mathrm{~K}$ with $2.92 \mathrm{ml} \mathrm{min}^{-1}$ water flowrate.

\begin{tabular}{cclccc}
\hline No & $\begin{array}{c}\text { Retention } \\
\text { time [min] }\end{array}$ & \multicolumn{1}{c}{ Compound name } & $\begin{array}{c}\text { Molecular } \\
\text { weight }\end{array}$ & Compound formula \\
\hline 1 & 5.33 & Urea & 60.06 & $\mathrm{CH}_{4} \mathrm{~N}_{2} \mathrm{O}$ \\
2 & 8.50 & 3-Pentanone & 86.13 & $\mathrm{C}_{5} \mathrm{H}_{10} \mathrm{O}$ \\
3 & 9.90 & 3-Methylbutanal & 86.13 & $\mathrm{C}_{5} \mathrm{H}_{10} \mathrm{O}$ \\
4 & 10.39 & 1-Hydroxy-2-butanone & 88.11 & $\mathrm{C}_{4} \mathrm{H}_{8} \mathrm{O}_{2}$
\end{tabular}




\begin{tabular}{|c|c|c|c|c|}
\hline 5 & 12.75 & 2-Furancarboxaldehyde & 96.08 & $\mathrm{C}_{5} \mathrm{H}_{4} \mathrm{O}_{2}$ \\
\hline 6 & 13.32 & 2-Furanmethanol & 98.10 & $\mathrm{C}_{5} \mathrm{H}_{6} \mathrm{O}_{2}$ \\
\hline 7 & 14.66 & Unknown & - & - \\
\hline 8 & 17.10 & Trimethyloxazole & 111.14 & $\mathrm{C}_{9} \mathrm{H}_{9} \mathrm{NO}$ \\
\hline 9 & 17.34 & Glycerin & 92.1 & $\mathrm{C}_{3} \mathrm{H}_{8} \mathrm{O}_{3}$ \\
\hline 10 & 17.40 & 2,3,5-Trimethylfuran & 110.15 & $\mathrm{C}_{7} \mathrm{H}_{10} \mathrm{O}$ \\
\hline 11 & 18.81 & 2,4-Imidazolidinedione & 114.10 & $\mathrm{C}_{4} \mathrm{H}_{6} \mathrm{~N}_{2} \mathrm{O}_{2}$ \\
\hline 12 & 19.73 & 2,5-Piperazinedione & 114.10 & $\mathrm{C}_{4} \mathrm{H}_{6} \mathrm{~N}_{2} \mathrm{O}_{2}$ \\
\hline 13 & 21.40 & 1-Methylmorpholine & 101.15 & $\mathrm{C}_{5} \mathrm{H}_{5} \mathrm{NO}$ \\
\hline 14 & 22.07 & Furan & 68.07 & $\mathrm{C}_{4} \mathrm{H}_{4} \mathrm{O}$ \\
\hline 15 & 22.70 & Styrene & 104.15 & $\mathrm{C}_{8} \mathrm{H}_{8}$ \\
\hline 16 & 23.73 & 3-Hydroxy-2,3-dihydromaltol & 144.13 & $\mathrm{C}_{6} \mathrm{H}_{8} \mathrm{O}_{4}$ \\
\hline 17 & 24.78 & Pyrocatechol & 110.11 & $\mathrm{C}_{6} \mathrm{H}_{6} \mathrm{O}_{2}$ \\
\hline 18 & 24.96 & 2,5-Piperazinedione & 114.10 & $\mathrm{C}_{4} \mathrm{H}_{6} \mathrm{~N}_{2} \mathrm{O}_{2}$ \\
\hline 19 & 25.44 & Persicol & 184.28 & $\mathrm{C}_{11} \mathrm{H}_{20} \mathrm{O}_{2}$ \\
\hline 20 & 25.71 & Dihydrobenzofuran & 120.15 & $\mathrm{C}_{8} \mathrm{H}_{8} \mathrm{O}$ \\
\hline 21 & 25.91 & 5-Hydrxoymethylfurfural & 126.11 & $\mathrm{C}_{6} \mathrm{H}_{6} \mathrm{O}_{3}$ \\
\hline 22 & 26.92 & 2-Methyl-1-butene oxide & 86.13 & $\mathrm{C}_{5} \mathrm{H}_{10} \mathrm{O}$ \\
\hline 23 & 27.83 & 4,8-Dimethylundecane & 184.36 & $\mathrm{C}_{13} \mathrm{H}_{28}$ \\
\hline 34 & 28.55 & Valproic Acid & 144.21 & $\mathrm{C}_{8} \mathrm{H}_{16} \mathrm{O}_{2}$ \\
\hline 25 & 28.88 & 2,3-Diethyl-5-methylpyrazine & 150.22 & $\mathrm{C}_{9} \mathrm{H}_{14} \mathrm{~N}_{2}$ \\
\hline 26 & 29.80 & 2,6-Dimethoxyphenol & 154.16 & $\mathrm{C}_{8} \mathrm{H}_{10} \mathrm{O}_{3}$ \\
\hline 27 & 31.37 & Vanillin & 152.15 & $\mathrm{C}_{8} \mathrm{H}_{8} \mathrm{O}_{3}$ \\
\hline 28 & 32.07 & D-Arabinose & 150.16 & $\mathrm{C}_{5} \mathrm{H}_{10} \mathrm{O}_{5}$ \\
\hline 29 & 32.14 & D-Galactose & 180.16 & $\mathrm{C}_{6} \mathrm{H}_{12} \mathrm{O}_{6}$ \\
\hline 30 & 32.27 & D-Mannose & 180.16 & $\mathrm{C}_{6} \mathrm{H}_{12} \mathrm{O}_{6}$ \\
\hline 31 & 33.67 & 4-Acetylguaiacol & 166.17 & $\mathrm{C}_{9} \mathrm{H}_{10} \mathrm{O}_{3}$ \\
\hline 32 & 34.74 & 3-Ethylphenyl acetate & 164.20 & $\mathrm{C}_{10} \mathrm{H}_{12} \mathrm{O}_{2}$ \\
\hline 33 & 35.11 & Vanillic acid & 168.15 & $\mathrm{C}_{8} \mathrm{H}_{8} \mathrm{O}_{4}$ \\
\hline 34 & 35.36 & Xanthosine & 284.24 & $\mathrm{C}_{10} \mathrm{H}_{12} \mathrm{~N}_{4} \mathrm{O}_{6}$ \\
\hline 35 & 35.81 & Phenylacetylene & 102.15 & $\mathrm{C}_{8} \mathrm{H}_{6}$ \\
\hline 36 & 36.13 & p-Methoxybenzaldoxime & 151.16 & $\mathrm{C}_{8} \mathrm{H}_{9} \mathrm{NO}_{2}$ \\
\hline 37 & 37.82 & Syringaldehyde & 182.17 & $\mathrm{C}_{9} \mathrm{H}_{10} \mathrm{O}_{4}$ \\
\hline 38 & 39.51 & Homovanillic acid methyl ester & 196.20 & $\mathrm{C}_{10} \mathrm{H}_{12} \mathrm{O}_{4}$ \\
\hline 39 & 39.77 & Eugenol methyl ether & 178.23 & $\mathrm{C}_{11} \mathrm{H}_{14} \mathrm{O}_{2}$ \\
\hline 40 & 40.66 & Perhydrophenanthrene & 192.34 & $\mathrm{C}_{14} \mathrm{H}_{24}$ \\
\hline 41 & 42.30 & 3-Methoxy-4-hydroxycinnamic acid & 194.18 & $\mathrm{C}_{10} \mathrm{H}_{10} \mathrm{O}_{4}$ \\
\hline 42 & 44.47 & Methyl diphenylacetate & 226.27 & $\mathrm{C}_{15} \mathrm{H}_{14} \mathrm{O}_{2}$ \\
\hline 43 & 44.90 & Asarone & 208.25 & $\mathrm{C}_{12} \mathrm{H}_{16} \mathrm{O}_{3}$ \\
\hline
\end{tabular}

Table 3. The main functional groups of the major constituents of Japanese rice straw.

\begin{tabular}{lll}
\hline \multicolumn{1}{c}{ Wave number $\left[\mathrm{cm}^{-1}\right]$} & \multicolumn{1}{c}{ Functional groups } & \multicolumn{1}{c}{ Compounds } \\
\hline $3600-3000$ & O-H stretching & Acid, methanol \\
$2860-2970$ & C- $\mathrm{H}_{\mathrm{n}}$ stretching & Alkyl, aliphatic, aromatic \\
$1700-1730,1510-1560$ & $\mathrm{C}=$ O stretching & Ketone and carbonyl
\end{tabular}




\begin{tabular}{lll}
1632 & $\mathrm{C}=\mathrm{C}$ & Benzene stretching ring \\
1613,1450 & $\mathrm{C}=\mathrm{C}$ stretching & Aromatic skeletal mode \\
$1470-1430$ & $\mathrm{O}-\mathrm{CH}_{3}$ & Methoxyl-O-CH \\
$1440-1400$ & $\mathrm{O}-\mathrm{H}$ bending & Acid \\
1402 & $\mathrm{C}-\mathrm{H}$ bending & \\
1232 & $\mathrm{C}-\mathrm{O}-\mathrm{C}$ stretching & Aryl-alkyl ether linkage \\
1215 & $\mathrm{C}-\mathrm{O}$ stretching & Phenol \\
1170,1082 & $\mathrm{C}-\mathrm{O}-\mathrm{C}$ stretching vibration & Pyranose ring skeletal \\
1108 & $\mathrm{O}-\mathrm{H}$ association & $\mathrm{C}-\mathrm{OH}$ \\
1060 & $\mathrm{C}-\mathrm{O}$ stretching and $\mathrm{C}-\mathrm{O}$ deformation & $\mathrm{C}-\mathrm{OH}$ (ethanol) \\
$700-900$ & $\mathrm{C}-\mathrm{H}$ & Aromatic hydrogen \\
$700-650$ & $\mathrm{C}-\mathrm{C}$ stretching & \\
\hline
\end{tabular}

Table 4. Elemental analysis results of solid residues analyzed by CHN analyzer, on average.

\begin{tabular}{cccccccc}
\hline \multirow{2}{*}{$\begin{array}{c}\text { Temperature } \\
{[\mathrm{K}]}\end{array}$} & $\begin{array}{c}\text { Flow rate } \\
{\left[\mathrm{ml} \mathrm{min}^{-1}\right]}\end{array}$ & \multicolumn{3}{c}{ Ultimate analysis [wt. \%, DAF } & \multicolumn{3}{c}{ Atomic ratio [-] } \\
\cline { 3 - 8 } Room $^{+}$ & - & $\mathrm{H}$ & $\mathrm{C}$ & $\mathrm{N}$ & $\mathrm{O} *$ & $\mathrm{H} / \mathrm{C}$ & $\mathrm{O} / \mathrm{C}$ \\
& 1.42 & 5.98 & 39.89 & 0.81 & 53.32 & 0.15 & 1.34 \\
443 & 2.92 & 6.02 & 43.29 & 0.79 & 50.03 & 0.14 & 1.16 \\
& 4.67 & 5.99 & 43.02 & 0.97 & 50.02 & 0.14 & 1.16 \\
\hline \multirow{4}{*}{473} & 1.42 & 6.19 & 43.89 & 0.91 & 49.01 & 0.14 & 1.12 \\
& 2.92 & 6.20 & 44.31 & 1.28 & 48.21 & 0.14 & 1.09 \\
& 4.67 & 6.32 & 43.98 & 1.13 & 48.57 & 0.14 & 1.10 \\
\hline & 1.42 & 6.21 & 44.70 & 1.32 & 47.77 & 0.14 & 1.07 \\
& 2.92 & 6.43 & 44.90 & 0.98 & 47.69 & 0.14 & 1.06 \\
& 4.67 & 6.33 & 44.40 & 1.23 & 48.06 & 0.14 & 1.08 \\
\hline
\end{tabular}

*The content of oxygen was determined by difference.

+Original sample. 
(a) Japanese rice straw

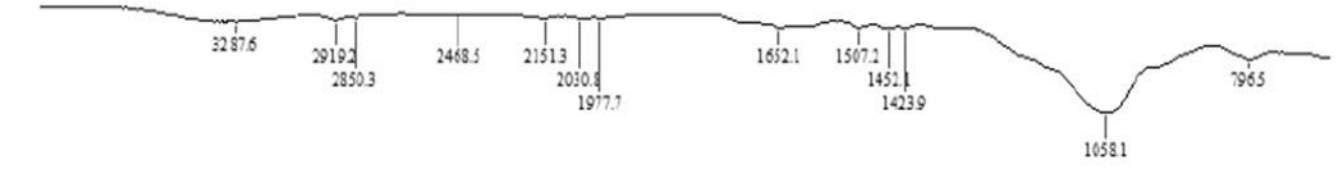

(b) Cellulose

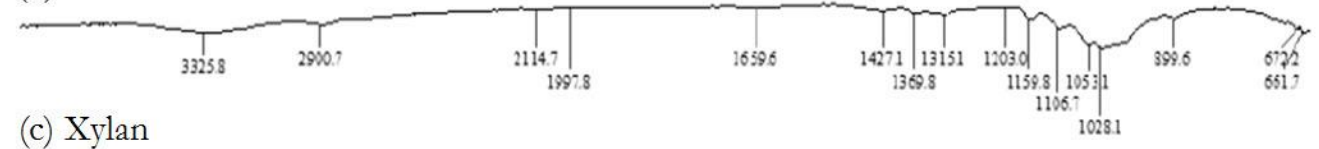

(c) Xylan

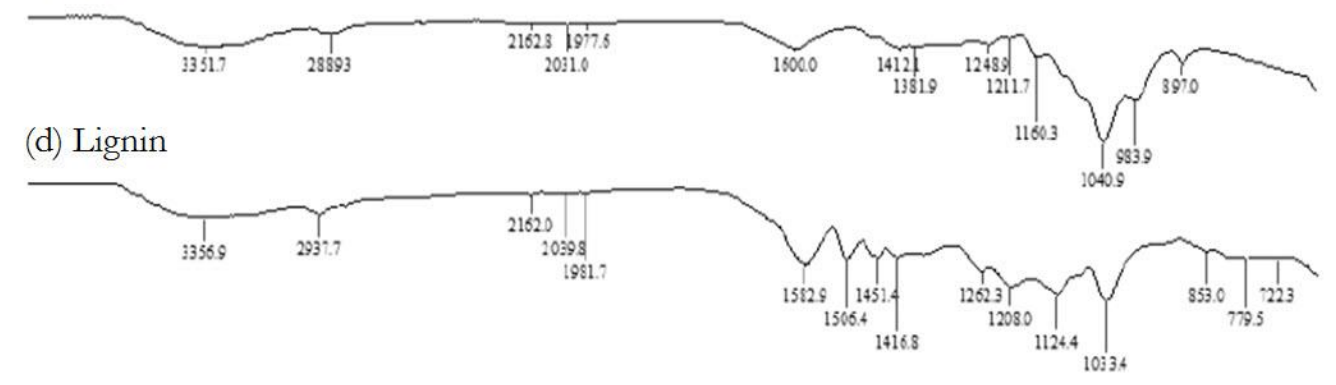

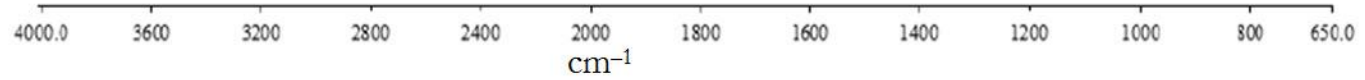

Fig. 6(a). FT-IR spectrum of Japanese rice straw and its major constituents.

(a) Lignin

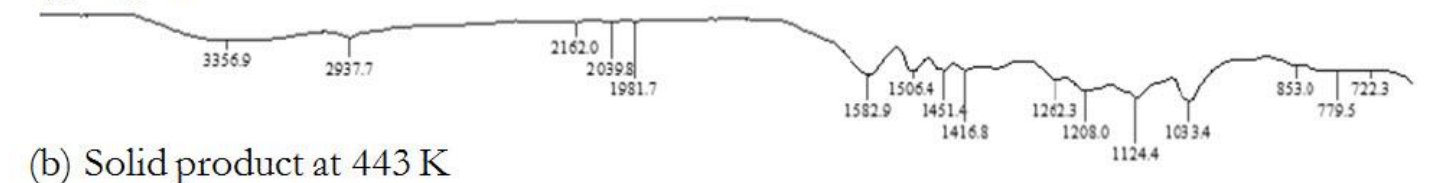

(b) Solid product at $443 \mathrm{~K}$

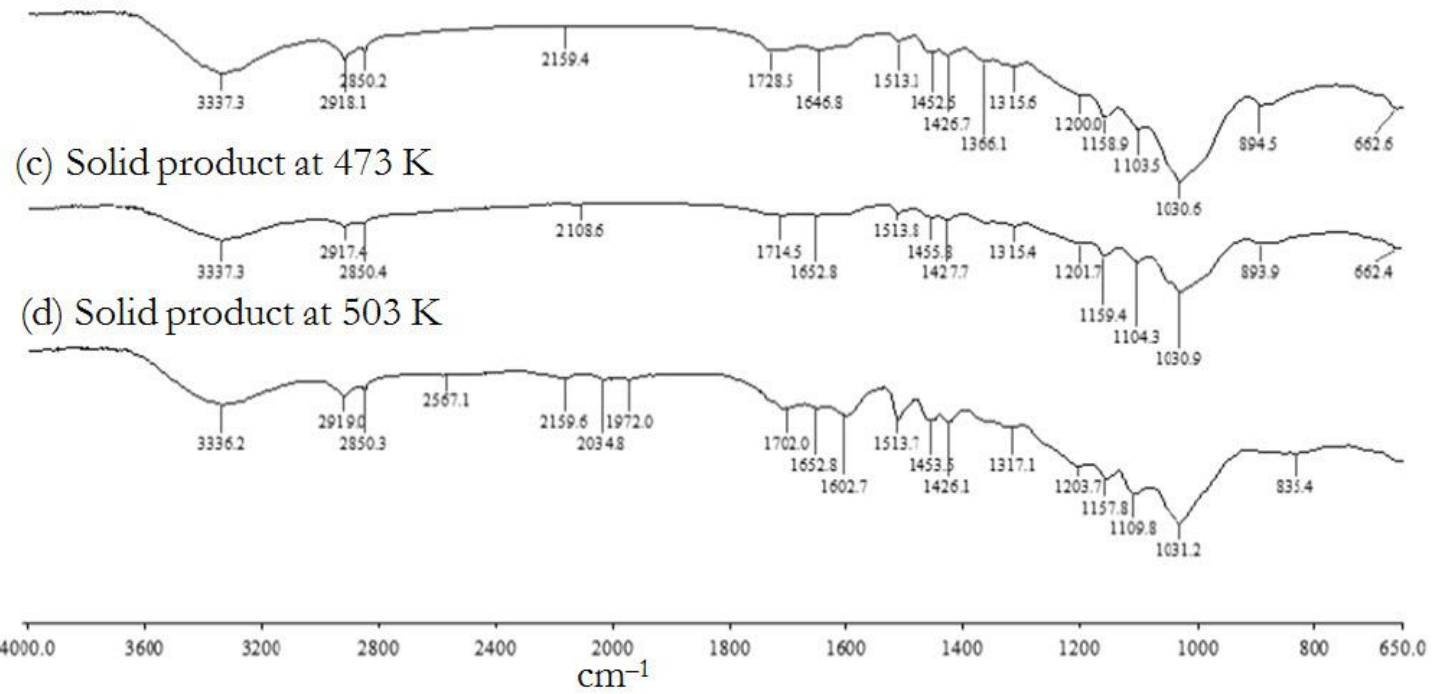

Fig. 6(b).FT-IR spectrum of solid products from Japanese rice straw extraction (a) 443, (b) 473, and (c) 503

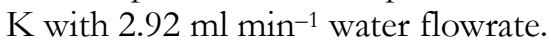

Table 4 shows the ultimate analysis of solid residue content in weight percent dry and ash free material (wt $\%$ DAF). The concentration of carbon increased gradually with increased water extraction flow rate at 443,473 , and $503 \mathrm{~K}$, respectively. The loss of hydrogen and oxygen in the solid residues is reflected in the decrease in hydrogen and oxygen content. These observations are in good agreement with results obtained by infrared spectroscopy of solid products, which shows an increase in the intensity of absorbance due to 
the hydrogen bonded. These results showed that dehydrogenation and deoxygenation occurred during the extraction process under these conditions [58-61]. It was reported by Nishimiya et al. 1998 [58] that the dehydrogenation and deoxygenation during the carbonization process of wood charcoal begin under dry conditions. Inoue et al. 2002 [59] also treated wood in hot compressed water to obtain charcoal, and then compare with dry conditions under a nitrogen atmosphere. They suggested that charcoal could be obtained from wood and that the dehydrogenation and deoxygenation in wood occurred during treatment with the hot compressed water. This indicates applicability of hot compressed water to such high-moisture biomass as Japanese rice straw, and that energy would be saved due to lack of necessity of drying.

As mentioned above, several methods, such as ultrasonic/microwave extraction, solvothermal extraction, ionic liquids solvent extraction, and liquid hot water extraction, were introduced to the extraction and separation of lignin as a one of the main components in biomass. Due to the complex process and less capacity of them, the development of extraction and separation technique for biomass components, such as lignin, is necessary. To reduce the use of organic solvent and improve the lignin extraction methods from plant biomass, hot compressed water extraction was applied at 443-503 K and 4.0 MP. It is a powerful technique at temperatures between 373 and $647 \mathrm{~K}$ and pressure high enough to maintain the liquid state leading to increased extraction efficiency through improvements in mass transfer and changes in the polarity of water. Under these conditions, water simultaneously acts as, reactant and catalyst. At conditions close to the critical point, water has several very interesting properties. Among them are low viscosity and high solubility of organic substances, which make hot compressed water an excellent medium for fast, homogeneous and efficient reactions. Hot compressed water was also called autohydrolysis, hydrothermal treatment, hydrothermolysis, liquid hot water, subcritical water, aquasolve process, aqueous processing and pressure-cooking in water [24]. Ruiz et al. 2013 [24] explained that hot compressed water has been considered a cost-effective pretreatment and in general, the major advantages of this process are: (1) the process does not require the addition and recovery of chemicals different from water, (2) limited equipment corrosion problems, (3) simple and economical operation.

Table 5. Properties of water under different conditions.

\begin{tabular}{lcccc}
\hline \multicolumn{1}{c}{ Fluid } & Ordinary water & Subcritical water & \multicolumn{2}{c}{ Supercritical water } \\
\hline Temperature $(\mathrm{K})$ & 298 & 523 & 673 & 673 \\
Pressure $(\mathrm{bar})$ & 1 & 50 & 250 & 500 \\
Density, $\rho\left(\mathrm{g} \mathrm{cm}^{-3}\right)$ & 1 & 0.80 & 0.17 & 0.58 \\
Dielectric constant, $\varepsilon$ & 78.5 & 27.1 & 5.9 & 10.5 \\
Ionic product, $p K_{\mathrm{w}}$ & 14.0 & 11.2 & 19.4 & 11.9 \\
Heat capacity $\left(\mathrm{kJ} \mathrm{kg}^{-1} \mathrm{~K}^{-1}\right)$ & 4.22 & 4.86 & 13.0 & 6.8 \\
Dynamic viscosity, $\eta\left(\mathrm{mPa} \mathrm{s}^{\prime}\right)$ & 0.89 & 0.11 & 0.03 & 0.07 \\
Heat conductivity, $\mathrm{Cp}\left(\mathrm{mW} \mathrm{m}^{-1} \mathrm{~K}^{-1}\right)$ & 608 & 620 & 160 & 438 \\
\hline
\end{tabular}

The hot compressed water (subcritical water) behaves very differently not only from water at room temperature but in some aspects also from supercritical water (see Table 5) [10]. The ionic product of water $\left(K_{\mathrm{W}}\right)$ is relatively high in the subcritical range ( $10^{12}$ compared to $10^{14}$ at ambient conditions). The high levels of $\mathrm{H}^{+}$and $\mathrm{OH}^{-}$at subcritical conditions mean that many acid- or base-catalyzed reactions, such as biomass hydrolysis, are accelerated [30, 10]. Furthermore, the density of subcritical water is in the range between those of ambient and supercritical conditions. Despite the high-temperature, the compressibility is still rather low. The relatively high density combined with the high dissociation constant of subcritical water, favors ionic reactions. Shi et al. 2012 [62] also explained that the extraction is, thus, based on the changing dielectric constant of water with temperature, which modifies the polarity of water making it capable of extracting different compounds. Also, the use of pressure of around $5 \mathrm{MPa}$ would be high enough to prevent the water from vaporizing at temperatures from 373 to $523 \mathrm{~K}$. Once pressure is high enough to keep water in a liquid state, additional pressure is not necessary as it has limited influence on the solvent characteristics of water. Increasing the water temperature from 298 to $573 \mathrm{~K}$ causes similar changes in dielectric constant, surface tension, and viscosity. They also explained that the hot compressed water extraction process has the ability to selectively extract different classes of compounds, depending on the temperature used. The selectivity of hot compressed water extraction allows for manipulation of the composition of the extracts by changing the operating parameters, with the more polar extracted at lower 
temperatures and the less polar compounds extracted at higher temperatures. For that reason, the hot compressed water extraction can be considered an environmentally friendly fractionation process. In addition, this technique is also suitable for processing high-moisture (wet) biomass since water is used as the extraction medium, and thus the biomass can be directly converted without an energy consuming drying step.

\section{Conclusions}

Hot compressed water extraction of lignin from the Japanese rice straw was studied at temperatures of 443-503 $\mathrm{K}$ and pressure of 4.0 MPa using a flow-through system. Under these conditions, thermal softening of the Japanese rice straw occurred, allowing the removal of the lignin protecting other constituents in Japanese rice straw. UV-vis spectrum revealed strong absorption peaks distributed at wavelengths in the region of $200-210 \mathrm{~nm}$ due to the high lignin content in extracted products. Lignin recovery approached $85 \%$ when the extraction was performed at 443 and $473 \mathrm{~K}$ with a flow rate of $4.67 \mathrm{ml}$ $\mathrm{min}^{-1}$; recovery increased with increased flow rate at each temperature. By ultimate analysis of solid residues, the concentration of carbon increased gradually with increased water extraction flow rate at 443, 473, and $503 \mathrm{~K}$, respectively. The loss of hydrogen and oxygen in the solid residues is reflected in the decrease in hydrogen and oxygen content. Based on these results, it is proposed that hot compressed water treatment is applicable to isolate lignin from other types of biomass.

\section{Acknowledgements}

This work was supported by the Kumamoto University Global COE Program "Global Initiative Center for Pulsed Power Engineering", NEDO (Development of Technology for High Efficiency Biomass Energy Conversions), and JSPS Fellowship from the Japan Society for the Promotion of Science (JSPS).

\section{References}

[1] E. Dorrestijn, L. J. J. Laarhoven, I. W. C. E. Arends, and P. Mulder, "The occurrence and reactivity of phenoxyl linkages in lignin and low rank coal," J. Anal. Appl. Pyrolysis, vol. 54, no. 1-2, pp. 153-192, Mar., 2000.

[2] N. Mosier, R. Hendrickson, N. Ho, M. Sedlak, and M. R. Ladisch, "Optimization of pH controlled liquid hot water pretreatment of corn stover," Bioresour. Technol., vol. 96 no. 18, pp. 1986-1993, Dec., 2005.

[3] H. Inoue, S. Yano, T. Endo, T. Sakaki, and S. Sawayama, "Combining hot-compressed water and ball milling pretreatments to improve the efficiency of the enzymatic hydrolysis of eucalyptus," Biotechnol. Biofuels., vol. 1, no. 2, Apr., 2008.

[4] J. B. Kristensen, L. G. Thygesen, C. Felby, H. Jorgensen, and T. Elder, "Cell-wall structural changes in wheat straw pretreated for bioethanol production," Biotechnol. Biofuels., vol. 1, no. 5, Apr., 2008.

[5] M. Carrier, A. Loppinet-Serani, C. Absalon, C. Aymonier, and M. Mench, "Degradation pathways of holocellulose, lignin and a-cellulose from Pteris vittata fronds in sub- and super critical conditions," Biomass Bioenergy, vol. 43, pp. 65-71, August, 2012.

[6] Wahyudiono, M. Sasaki, M. Goto, "Recovery of phenolic compounds through the decomposition of lignin in near and supercritical water," Chem. Eng. Process., vol. 47, no. 9-10, pp. 1609-1619, Sep., 2008.

[7] M. Saisu, T. Sato, M. Watanabe, T. Adschiri, and K. Arai, "Conversion of lignin with supercritical water-phenol mixtures," Energy Fuels, vol. 17, no. 4, pp. 922-928, May, 2003.

[8] Y. Ye, J. Fan, and J. Chang, "Effect of reaction conditions on hydrothermal degradation of cornstalk lignin," J. Anal. Appl. Pyrolysis, vol. 94, pp. 190-195, Mar., 2012.

[9] H. Pinkowska, P. Wolak, and A. Zlocinska, "Hydrothermal decomposition of alkali lignin in sub- and supercritical water," Chem. Eng. Journal, vol. 187, pp. 410-414, Apr., 2012.

[10] Wahyudiono, S. Machmudah, and M. Goto, "Utilization of sub and supercritical water reactions in resource recovery of biomass wastes," Eng. Journal, vol. 17, no. 1, 2013. doi:10.4186/ ej.2013.17.1.1

[11] V. Sricharoenchaikul, "Assessment of black liquor gasification in supercritical water," Bioresour. Technol., vol. 100, no. 2, pp. 638-643, Jan., 2009. 
[12] M. Osada, T. Sato, M. Watanabe, M. Shirai, and K. Arai, "Catalytic gasification of wood biomass in subcritical and supercritical water," Combust. Sci. Technol., vol. 178, no. 1-3, pp. 537-552, Jan., 2006.

[13] Y. Yoshida, Y. Oshima, and Y. Matsumura, "Gasification of biomass model compounds and real biomass in supercritical water," Biomass Bioenergy, vol. 26, no. 1, pp. 71-78, Jan., 2004.

[14] H. Jin, Y. Lu, L. Guo, X. Zhang, and A. Pei, "Hydrogen production by supercritical water gasification of biomass with homogeneous and heterogeneous catalyst," Adv. Cond. Matt. Phys., vol. 2014, Jun., 2014.

[15] S. Kang, X. Li, J. Fan, and J. Chang, "Hydrothermal conversion of lignin: A review," Renew. Sustain. Energy Rev., vol. 27, pp. 546-558, Nov., 2013.

[16] Y. Sun and J. Cheng, "Hydrolysis of lignocellulosic materials for ethanol production: A review," Bioresour. Technol., vol. 83, no. 1, pp. 1-11, May, 2002.

[17] C. E. Wyman, B. E. Dale, R. T. Elander, M. Holtzapple, M. R. Ladisch, and Y. Y. Lee, "Comparative sugar recovery data from laboratory scale application of leading pretreatment technologies to corn stover," Bioresour. Technol., vol. 96, no. 18, pp. 1959-1966, Dec., 2005.

[18] F. Talebnia, D. Karakashev, and I. Angelidaki, "Production of bioethanol from wheat straw: An overview on pretreatment, hydrolysis and fermentation," Bioresour. Technol., vol. 101, no. 13, pp. 4744 4753, Jul., 2010.

[19] M. Goto, T. Nada, A. Ogata, A. Kodama, and T. Hirose, "Supercritical water oxidation for the destruction of municipal excess sludge and alcohol distillery wastewater of molasses," J. Supercrit. Fluids, vol. 13, no. 1, pp. 277-282, Jun., 1998.

[20] M. Sasaki, B. Kabyemela, R. Malaluan, S. Hirose, N. Takeda, T. Adschiri, and K. Arai, "Cellulose hydrolysis in subcritical and supercritical water," J. Supercrit. Fluids, vol. 13, no. 1, pp. 261-268, Jun., 1998.

[21] Wahyudiono, M. Sasaki, and M. Goto, "Kinetic study for liquefaction of tar in sub- and supercritical water," Polymer Degradation and Stability, vol. 93, no. 6, pp. 1194-1204, Jun., 2008.

[22] F. P. Cardenas-Toro, S. C. Alcazar-Alay, T. Forster-Carneiro, and M. A. A. Meireles, "Obtaining oligo- and monosaccharides from agroindustrial and agricultural residues using hydrothermal treatments," Food and Public Health, vol. 4 no. 3, pp. 123-139, 2014. doi: 10.5923/j.fph.20140403.08

[23] S. I. Aronovsky and R. A. Gortner, "The cooking process I-Role of water in the cooking of wood," Ind. Eng. Chem., vol. 22, no. 3. pp. 264-274, Mar., 1930.

[24] He. A. Ruiz, R. M. Rodriguez-Jasso, B. D. Fernandes, A. A. Vicente, and J. A. Teixeira, "Hydrothermal processing, as an alternative for upgrading agriculture residues and marine biomass according to the biorefinery concept: A review," Renew. Sustain. Energy Rev., vol. 21, pp 35-51, May, 2013.

[25] W. L. Marshall and E. U. Franck, "Ion product of water substance, 0-1000 ${ }^{\circ} \mathrm{C}, 1-10,000$ bars new international formulation and its background," J. Phys. Chem. Ref. Data, vol. 10, no. 2, pp. 295-304, 1981.

[26] W. S. L. Mok and M. J. Antal Jr., "Uncatalyzed solvolysis of whole biomass hemicellulose by hot compressed liquid water," Ind. Eng. Chem. Res., vol. 31, no. 4, pp. 1157-1161, Apr., 1992.

[27] T. Rogalinski, T. Ingram, and G. Brunner, "Hydrolysis of lignocellulosic biomass in water under elevated temperatures and pressures," J. Supercrit. Fluids, vol. 47, no. 1, pp. 54-63, Nov., 2008.

[28] R. Chandra, H. Takeuchi, and T. Hasegawa, "Hydrothermal pretreatment of rice straw biomass: A potential and promising method for enhanced methane production," Appl. Energy, vol. 94, pp. 129_ 140, Jun., 2012.

[29] N. Mosier, C. Wyman, B. Dale, R. Elander, Y. Y. Lee, M. Holtzapple, and M. Ladisch, "Features of promising technologies for pretreatment of lignocellulosic biomass," Bioresour. Technol., vol. 96, no. 6, pp. 673-686, Apr., 2005.

[30] S. S. Toor, L. Rosendahl, and A. Rudolf, "Hydrothermal liquefaction of biomass: A review of subcritical water technologies," Energy, vol. 36, no. 5, pp. 2328-2342, May, 2011.

[31] A. Converti, B. Aliakbarian, J. M. Dominguez, G. Bustos Vazquez, and P. Perego. "Microbial production of biovanillin," Bra: J. Microbiol., vol. 41, no. 3, pp. 519-530, 2010.

[32] R. Hatfield and R. S. Fukushima, "Can lignin be accurately measured?," Crop Sci., vol. 45, no. 3. pp. 832-839, May, 2005.

[33] S. Y. Lin and C. W. Dence, (Eds.), Methods in Lignin Chemistry. Berlin-Heidelberg: Springer-Verlag, 1992, ch. 2, pp. 33-58. 
[34] D. N. S. Hon and N. Shiraishi, Wood and Cellulosic Chemistry, 2nd ed, revised and expanded. New York: Marcel Dekker, Inc., 2001, ch. VIII, sec. VI, pp. 315-352.

[35] G. Wegener, M. Przyklenk, and D. Fengel, "Hexafluoropropanol as a valuable solvent for lignin in UV and IR spectroscopy," Holizforschung, vol. 37, no. 6, pp. 303-306, Jan., 1983.

[36] F. Maekawa, T. Ichikawa, and T. Koshijima, "An evaluation of the acid-soluble lignin determination in analysis of lignin by the sulfuric acis method," J. Wood. Chem. Technol., vol. 9, no 4, pp. 549-567, Oct., 1989.

[37] M. S. Jahan and S. P. Mun, "Characteristics of dioxane lignins isolated at different ages of Nalita wood (Trema orientalis)," J. Wood. Chem. Technol., vol. 27, no. 2, Jul., 2007.

[38] T. Minowa, Z. Fang, T. Ogi, and V. Varhegyi, "Decomposition of cellulose and glucose in hotcompressed water under catalyst-free conditions," J. Chem. Eng. Japan, vol. 31, no. 1, pp. 131-134, Apr., 1998.

[39] J. K. Ko, Y. Kim, E. Ximenes, and M. R. Ladisch, "Effect of liquid hot water pretreatment severity on properties of hardwood lignin and enzymatic hydrolysis of cellulose," Biotechnol. Bioeng., vol. 112, no. 2, pp. 252-262, Oct., 2014.

[40] G. Vazquez, G. Antorrena, J. Gonzalez, S. Freire, and S. Lopez, "Acetosolv pulping of pine wood. Kinetic modelling of lignin solubilization and condensation," Bioresour. Technol., vol. 59, no. 2, pp. 121 127, Feb.-Mar., 1997.

[41] C. Liu and C. E. Wyman, "The effect of flow rate of compressed hot water on xylan, lignin, and total mass removal from corn stover," Ind. Eng. Chem. Res., vol. 42, no. 21, pp. 5409-5416, Sept., 2003.

[42] A. Demirbas, "Mechanisms of liquefaction and pyrolysis reactions of biomass," Energy Conv. Manag., vol. 41, no. 6, pp. 633-646, Apr., 2000.

[43] G. Guo, S. Li, L. Wang, S. Ren, and G. Fang, "Separation and characterization of lignin from bioethanol production residue," Bioresour. Technol., vol. 135, pp. 738-741, May, 2013.

[44] K. A. Buranov and R. G. Mazza, "Isolation and characterization of lignins extracted from flax shives using pressurized aqueous ethanol," Bioresour. Technol., vol. 101, no. 19, pp. 7446-7455, Oct., 2010.

[45] M. F. Li, Y. M. Fan, R. C. Sun, and F. Xu, "Characterization of extracted lignin of bamboo (Neosinocalamus affinis) pretreated with sodium hydroxide/urea solution at low temperature," BioResources, vol. 5, no. 3, pp. 1762-1778, Aug., 2010.

[46] S. H. Lee, T. V. Doherty, R. J. Linhardt, and J. S. Dordick, "Ionic liquid-mediated selective extraction of lignin from wood leading to enhanced enzymatic cellulose hydrolysis," Biotechnol. Bioeng., vol. 102, no. 5, pp. 1368-1376, Apr., 2009.

[47] R. C. Sun, J. Tomkinson, "Characterization of hemicelluloses isolated with tetraacetylethylenediamine activated peroxide from ultrasound irradiated and alkali pre-treated wheat straw," Eur. Polym. J., vol. 39, no. 4, pp. 751-759, Apr., 2003.

[48] R. C. Sun, X. F. Sun, and X. P. Xu, "Effect of ultrasound on the physicochemical properties of organosolv lignins from wheat straw," J. Appl. Polym. Sci., vol. 84, no. 13, pp. 2512-2522, Jun., 2002.

[49] P. Rangsriwong, N. Rangkadilok, J. Satayavivad, M. Goto, and A. Shotipruk, "Subcritical water extraction of polyphenolic compounds from Terminalia chebula Retz. Fruits," Sep. Pur. Technol., vol. 66, no. 1, pp. 51-56, Apr., 2009.

[50] Y. Matsunaga, Wahyudiono, S. Machmudah, M. Sasaki, and M. Goto, "Hot compressed water extraction of polysaccharides from Ganoderma lucidum using a semibatch reactor," Asia-Pac. J. Chem. Eng., vol. 9, no. 1, pp. 125-133, Jan./Feb., 2014.

[51] B. H. Klinke, B. K. Ahring, S. A. S. Schmidt, and A. B. Thomsen, "Characterization of degradation products from alkaline wet oxidation of wheat straw," Bioresour. Technol., vol. 82, no. 1, pp. 15-26, March, 2002.

[52] M. Tymchyshyn and C. Xu, "Liquefaction of bio-mass in hot-compressed water for the production of phenolic compounds," Bioresour. Technol., vol. 101, no. 7, pp. 2483-2490, Apr., 2010.

[53] Z. Yuan, S. Cheng, M. Leitch, and C. Xu, "Hydrolytic degradation of alkaline lignin in hot-compressed water and ethanol," Bioresour. Technol., vol. 101, no. 23, pp. 9308-9313, Dec., 2010.

[54] X. Z. Yuan, J. Y. Tong, G. M. Zeng, H. Li, and W. Xie, "Comparative studies of products obtained at different temperatures during straw liquefaction by hot compressed water," Energy Fuels, vol. 23, no. 6, pp. 3262-3267, Apr., 2009.

[55] R. Rana, R. Langenfeld-Heyser, R. Finkeldey, and A. Polle, "FTIR spectroscopy, chemical and histochemical characterisation of wood and lignin of five tropical timber wood species of the family of Dipterocarpaceae," Wood. Sci. Technol., vol. 44, no. 2, pp 225-242, May., 2010. 
[56] K. Bilba and A. Ouensanga, "Fourier transform infrared spectroscopic study degradation of sugar cane bagasse," J. Anal. Appl. Pyrolysis, vol. 38, no. 1-2, pp. 61-73, Dec., 1996.

[57] C. G. Boeriu, D. Bravo, R. J. A. Gosselink, and J. E. G. van Dam,"'Characterisation of structuredependent functional properties of lignin with infrared spectroscopy," Ind. Crops Products, vol. 20, no. 2, pp. 205-218, Sept., 2004.

[58] K. Nishimiya, T. Hata, Y. Imamura, and S. Ishihara, "Analysis of chemical structure of wood charcoal by X-ray photoelectron spectroscopy," J. Wood Sci., vol. 44, no. 1, pp. 56-61, Feb., 1998.

[59] S. Inoue, T. Hanaoka, and T. Minowa, "Hot compressed water treatment for production of charcoal from wood," J. Chem. Eng. Japan, vol. 35, no. 10, pp. 1020-1023, Dec., 2002.

[60] A. Funke and F. Ziegler, "Heat of reaction measurements for hydrothermal carbonization of biomass," Bioresour. Technol., vol. 102, no. 16, pp. 7595-7598, Aug., 2011.

[61] X. Lu, B. Jordan, and N. D. Berge, "Thermal conversion of municipal solid waste via hydrothermal carbonization: Comparison of carbonization products to products from current waste management techniques," Waste Management, vol. 32, no. 7, pp. 1353-1365, Jul., 2012.

[62] J. I. Boye and Y. Arcand, Green Technologies in Food Production and Processing. Heidelberg: Springer Science \& Business Media, LLC, 2012, ch. 11, pp. 285-289. 